\title{
Diversity in Grain, Flour, Amino Acid Composition, Protein Profiling, and Proportion of Total Flour Proteins of Different Wheat Cultivars of North India
}

\author{
Raashid Ahmad Siddiqi ${ }^{1}$, Tajendra Pal Singh ${ }^{1,2}$, Monika Rani ${ }^{1}$, Dalbir Singh Sogi ${ }^{1 *}$ and \\ Mohd Akbar Bhat ${ }^{3}$
}

${ }^{1}$ Department of Food Science and Technology, Guru Nanak Dev University, Amritsar, India, ${ }^{2}$ Department of Food Technology, Eternal University, Baru Sahib, Himachal Pradesh, India, ${ }^{3}$ Multidisciplinary Research Unit, Government Medical College,

Amritsar, India

OPEN ACCESS

Edited by:

Lovemore Nkhata Malunga Morden Research and Development Centre, Agriculture and Agri-Food

Canada, Canada

Reviewed by:

Sándor Tömösközi,

Budapest University of Technology and Economics, Hungary

Shiyi Ou,

Jinan University, China

*Correspondence:

Dalbir Singh Sogi

sogids@gmail.com

Specialty section:

This article was submitted to

Food Chemistry,

a section of the journal

Frontiers in Nutrition

Received: 13 April 2020

Accepted: 20 July 2020

Published: 08 September 2020

Citation: Siddiqi RA, Singh TP, Rani M, Sogi DS and Bhat MA (2020) Diversity in Grain,

Flour, Amino Acid Composition,

Protein Profiling, and Proportion of Total Flour Proteins of Different Wheat

Cultivars of North India.

Front. Nutr. 7:141

doi: 10.3389/fnut.2020.00141
Wheat cultivars grown at three different locations in North India were assessed for their variability in kernel and flour characteristics. Protein and the wet and dry gluten contents of the flour varied significantly $(p \leq 0.05)$ from 9.32 to $12.60 \%, 23.46$ to $43.04 \%$, and from 8.28 to $15.00 \%$, respectively. Wheat varieties exhibited moderate sodium dodecyl sulfate (SDS) sedimentation and solvent retention values. Flour showed a significant $(p \leq 0.05)$ difference in the amino acid composition. Lysine, having the lowest chemical score, was the first most limiting amino acid in all wheat varieties. The variability of total flour proteins determined by SDS-PAGE showed polymorphism both in the number and intensity of bands, particularly in the molecular weight range of 35.1-42.8 $\mathrm{kDa}$ corresponding to the $\alpha-, \beta$-, and $\gamma$-gliadin/low-molecular-weight glutenin subunit (LMW-GS) region. Pearson's correlation established between the various grain and flour parameters showed a significant correlation, which can result in better end product use.

Keywords: wheat grains, flour, protein, gluten, amino acids, solvent retention capacity, color, SDS-PAGE

\section{INTRODUCTION}

Wheat is one of the most cultivated crops in the world and is the principal source of energy, protein, fiber, vitamins, and phytochemicals to nearly 2.5 billion people $(1,2)$. The global production of wheat forecasted for the year 2020 is 763 million tons (3).

Wheat grains are found in different sizes, shapes, weights, and colors. Knowledge of the physical parameters, such as size, shape, porosity, sphericity, aspect ratio, and thousand kernel wheat is important for designing equipment meant for cleaning, grading, separation, storage, transportation, packaging, and aeration and for estimating yield during milling $(4,5)$. Color is one of the most important quality attributes determining the consumers' acceptance of a particular food (6). The color in wheat is due to the presence of tocols, anthocyanins, and phenolic compounds, which are known to have beneficial effects on human health. The distribution of these pigments is known to vary with genotypes and different environmental conditions, thus giving rise to varied colored wheat varieties. (7).

The wheat varieties grown in India are not only numerous but also show wide diversification in the physicochemical, rheological, and functional properties (8). Kundu et al. (9) reported a significant variation in the physicochemical and flour characteristics of the same wheat varieties 
grown at different locations. The end product quality has been reported to be affected by the flour protein content, the wet and dry gluten contents (10), and the proportion of the different protein fractions, i.e., high-molecular-weight glutenin subunit (HMW-GS), low-molecular-weight glutenin subunit (LMWGS), $\alpha-, \gamma-$, and $\omega$-gliadins, albumins, and globulins (11-14). More than $90 \%$ of the wheat cultivated in India is used for chapatti making, while the rest is used to make bread, pastries, biscuits, noodles, etc. Due to the varied genetic makeup and environmental conditions, it has become very difficult for bakers to obtain flour of consistent quality for making products.

The amino acid composition of wheat is quite unbalanced, lacking the essential amino acids like lysine, threonine, and methionine. Processing wheat into various products further depletes it of essential amino acids $(15,16)$. Anjum et al. (17) found that the newly released wheat varieties are nutritionally more superior than the old wheat varieties, especially in the percentages of essential amino acids, particularly lysine. Nutritional profiling of the plant foods, along with their suitability for different end product uses without compromising the quality, has become of utmost importance due to the growing trend toward organic and vegan foods. Thus, better knowledge and understanding of the various physicochemical properties, protein quality, polymorphism of the various protein fractions, and information on the amino acid composition of the varieties will be beneficial not only to plant breeders but also to processors for the manufacturing of food products without affecting their nutritional value.

To our best knowledge, none of the earlier studies has reported on the flour characteristics, protein profiling, proportion of the different protein fractions, and information on the amino acid composition together and none correlated a relation between all these parameters. This study was undertaken to evaluate the variability in the grain, flour, amino acid composition, and proportions of the different flour proteins along with their correlations.

\section{MATERIALS AND METHODS}

\section{Raw Material}

Certified wheat varieties were procured from Punjab Agriculture University Ludhiana, Punjab, India (DBW-17, HD-2851, HD-2967, HD-3086, PBW-175, PBW-502, PBW-550, PBW621, PBW-664, and PBW-660); Sher-e-Kashmir University of Agricultural Sciences and Technology, Srinagar, India (SW-1 and SW-2); and G.B. Pant University of Agriculture and Technology, Pantnagar, India (UP-262 and WH-1105). The wheat varieties were selected based on their different geographical locations, with geological coordinates as follows: Ludhiana (longitude $75^{\circ} 51^{\prime} 26.1972^{\prime \prime} \mathrm{E}$, latitude $30^{\circ} 54^{\prime} 3.4740^{\prime \prime} \mathrm{N}$, altitude 252 m.a.s.l.); Srinagar (longitude $74^{\circ} 47^{\prime} 50.5356^{\prime \prime} \mathrm{E}$, latitude $34^{\circ} 5^{\prime} 1.1616^{\prime \prime} \mathrm{N}$, altitude 1,587 m.a.s.l.); and Pantnagar (longitude $79^{\circ} 29^{\prime} 23.06^{\prime \prime} \mathrm{E}$, latitude $29^{\circ} 1^{\prime} 15.74^{\prime \prime} \mathrm{N}$, altitude 236.54 m.a.s.l.). The seeds were cleaned to remove all kinds of foreign materials like stones, dust, dirt, and broken and immature grains. The cleaned seeds from each variety were tempered with distilled water to a moisture content of $14 \%$ and left for $24 \mathrm{~h}$ at $4^{\circ} \mathrm{C}$ to equilibrate the moisture content for good bran separation. The conditioned grains were milled in a Brabender Quadrumat junior mill (Brabender OHG, Germany) to obtain white flour (72\% extraction rate). The flour obtained was kept in airtight jars at $-20^{\circ} \mathrm{C}$ until further use and thawed for $2 \mathrm{~h}$ at $25^{\circ} \mathrm{C}$ before use. All the chemicals used were of analytical grade or higher.

\section{Grain Characteristics}

The length, width, and thickness of the wheat grains were measured using a vernier caliper with the lowest reading of $0.02 \mathrm{~mm}$. The equivalent diameter $\left(D_{\mathrm{m}}\right)$, sphericity, grain volume ( $V$, in cubic millimeters), surface area ( $S$, in square millimeters), and porosity were calculated using the relationship given by Mohsenin (18). The aspect ratio $\left(R_{\mathrm{a}}\right)$ of the wheat grains was calculated as reported by Omobuwajo et al. (5). The bulk density and hundred seed volume were determined following the method of Wani et al. (4), and true density was determined using the toluene displacement method (19).

\section{Flour Characteristics Proximate Composition}

Moisture (44-15.02), protein (46-12.01), ash (08-02.01), fiber (32-10.01), and fat (30-25.01) were determined following the approved method of the American Association of Cereal Chemists (20). Carbohydrate was calculated by the difference and energy by multiplying the protein and carbohydrate by 4 and fat by 9 , respectively.

\section{Solvent Retention Capacity}

Solvent retention capacity (SRC) was calculated according to the procedure of Ram et al. (21), with minor modifications. A flour sample ( $1 \mathrm{~g}$ ) was individually suspended in $5 \mathrm{ml}$ of distilled water, $5 \%$ sodium carbonate, $50 \%$ sucrose, and $5 \%$ lactic acid in a $15-$ $\mathrm{ml}$ centrifuge tube with a conical bottom and shaken vigorously for $5 \mathrm{~s}$ to suspend the flour. The samples were then placed horizontally on a shaking incubator (LSI-3016R, Daihan Lab Tech Co., Ltd., Namyangju, Kyonggi, South Korea) operating at $150 \mathrm{rpm}$ for $20 \mathrm{~min}$ at room temperature to allow them to hydrate and solvate. Suspended samples were then centrifuged at 1,000 $\times$ $g$ for $15 \mathrm{~min}$ at $25^{\circ} \mathrm{C}$. The supernatant was poured off and the sample tubes were drained at a $90^{\circ}$ angle for $15 \mathrm{~min}$ and weighed. The SRC values were calculated with the following formula:

$$
\begin{aligned}
\mathrm{SRC}(\mathrm{g} / 100 \mathrm{~g})= & \frac{\text { Wet pellet }(\mathrm{g})}{\text { Flour }(\mathrm{g})}-1 \\
& \times \frac{86}{100-\text { Flour moisture }(\mathrm{g} / 100 \mathrm{~g})} \times 100
\end{aligned}
$$

\section{Gluten Performance Index}

Gluten performance index (GPI) was determined using the SRC data following the formula of Kweon et al. (22).

$$
\mathrm{GPI}=\frac{\text { Lactic acid SRC }}{\text { Sodium carbonate SRC }+ \text { Sucrose SRC }}
$$

\section{SDS Sedimentation Value}

The sodium dodecyl sulfate (SDS) sedimentation value was determined using the procedure outlined by Axford et al. (23). 
Five grams flour was added into a 50-ml measuring cylinder with a stopper and the contents mixed vigorously for $15 \mathrm{~s}$. After 2 and $4 \mathrm{~min}$, the flour contents were again thoroughly mixed for $15 \mathrm{~s}$. Promptly, $50 \mathrm{ml}$ of the freshly prepared SDS-lactic acid reagent (prepared by adding $2 \mathrm{~g}$ SDS in $100 \mathrm{ml}$ of water and adding $2 \mathrm{ml}$ of stock-diluted lactic acid solution, one part lactic acid plus eight parts of water by volume) was added and mixed in by inverting the cylinder four times before restarting the clock from zero again. Inversion was repeated four times at 2, 4, and $6 \mathrm{~min}$ before the clock was started once again from zero time. The cylinder contents were allowed to settle down for $40 \mathrm{~min}$ before the sedimentation values were recorded.

\section{Gluten Content}

Wet and dry gluten were determined as per the approved method $38-10$ (20) by hand washing the dough of wheat flour $(25 \mathrm{~g})$ to remove the starch and other soluble components.

\section{Color of Wheat Grains/Flour}

The color of the wheat grains and flour was determined using UltraScan VIS Hunter Color Lab (Hunter Associates Laboratory Inc., Reston VA., USA) following the procedure of Siddiqi et al. (24). The system was calibrated before measurements using black and white tiles. Samples were taken in a glass cell, housed in a black box, and illuminated with a light source. Color readings were communicated in terms of $L^{*}$, which indicates brightness (0-100 representing dark to whiteness); $a^{*}$, measuring the color parameter, red to green (positive values being red and negative values being green); and $b^{*}$, measuring the chromaticity parameter, blue to yellow (positive values being yellow and negative values being blue).

Chroma, which is the quality of color purity, intensity, or saturation of a single color, was calculated by using formula: $\left(a^{* 2}\right.$ $\left.+b^{* 2}\right)^{0.5}$.

Hue value measures the most apparent value of color calculated by using $\tan ^{-1}\left(b^{*} / a^{*}\right)^{2}$.

The total color difference $(\Delta E)$ was calculated using the following formula:

$$
\Delta E=\left(\mathrm{d} L^{*}\right)+\left(\mathrm{d} a^{*}\right)+\left(\mathrm{d} b^{*}\right)^{1 / 2} .
$$

\section{Amino Acid Analysis}

Samples $(15 \mathrm{mg}$ ) of flour (defatted) were hydrolyzed in screwcapped test tubes which were dipped overnight in $2 \mathrm{~N}$ hydrochloric acid (HCL) to avoid any sort of contamination. Hydrolysis was carried out using $6 \mathrm{~N}$ HCL containing $0.1 \%$ phenol in an oven at $110 \pm 1^{\circ} \mathrm{C}$ for $24 \mathrm{~h}$. Very tight closure of the screw-capped test tubes prevents loss of HCL during the hydrolysis process. The filtrate was evaporated under vacuum at $60^{\circ} \mathrm{C}$ to dryness in a rotary evaporator (Buchi, Fawil, Switzerland). A suitable volume of $0.1 \mathrm{~N}$ HCL was added to each dried film of the hydrolyzed sample. After all the soluble materials were dissolved, the samples were filtered through a $0.22-\mu \mathrm{m}$ filter paper (Millipore, Merck Life Science Private Limited, Mumbai, India). Amino acid analysis was performed using a Nexera Amino Acid Analyzer (Shimadzu, Kyoto Japan) equipped with pre-column derivatization. The amino acids were derivatized using mercaptopropionic acid, $o$-phthalaldehyde, and 9-fluorenylmethyl chloroformate. Chromatographic separation was carried using a Waters Spherisorb ODS2 Column (80 A, $5 \mu \mathrm{m}, 4.6 \mathrm{~mm} \times 250 \mathrm{~mm})$ with $\mathrm{pH}$ stability $2-8$. The analysis was performed using $20 \mathrm{mmol} / \mathrm{L}$ phosphate (potassium) buffer ( $\mathrm{pH}$ 6.5) as solvent A and 45:40:15 acetonitrile/methanol/water as solvent $\mathrm{B}$. The separation was obtained at a flow rate of $1 \mathrm{ml} / \mathrm{min}$ using a gradient elution that allowed for $0 \mathrm{~min}$ at $2 \% \mathrm{~B}$ followed by a $41-$ min step that raised eluent B to $50 \%$. Solvent B was then again decreased to $2 \%$ in a 43 -min step for a total analysis time of $44 \mathrm{~min}$. The temperature of the column oven was set at $40^{\circ} \mathrm{C}$ and the injection volume was $1 \mu \mathrm{l}$. The resolution of the amino acid derivatives was monitored through a fluorescence detector with excitation and emission set at 330 and $450 \mathrm{~nm}$, respectively. Lab solutions LC/GC (Shimadzu) was used as a working station. The amino acid standard mixture was prepared by mixing 18 different amino acids (SRL, Mumbai-India) in $0.1 \mathrm{~N} \mathrm{HCL}$ and included aspartic acid (Asp), threonine (Thr), serine (Ser), glutamic acid (Glu), proline (Pro), glycine (Gly), alanine (Ala), cysteine (Cys), methionine (Met), tyrosine (Tyr), arginine (Arg), phenylalanine (Phe), valine (Val), leucine (Leu), isoleucine (Ile), lysine (Lys), tryptophan (Trp), and histidine (His). The retention time of each standard in the mixture was compared with those of the digested samples and quantified by comparing the area of the sample with that of the standard mixture.

\section{Amino Acid Score}

The amino acid score (AAS) of each flour sample was calculated by comparing the proportion of each amino acid with that of the amino acid in the reference protein, as provided by the Food and Agriculture Organization (16) based on the amino acid requirement of a child (6 months to 3 years):

$$
\text { AAS }=\frac{\text { Amino acid in test protein }(\mathrm{g})}{\text { Amino Acid in refrence protein }(\mathrm{g})} \times 100
$$

The essential amino acids required by a child (6 months to 3 years $)$ are histidine $(2 / 100 \mathrm{~g})$, isoleucine $(3.2 / 100 \mathrm{~g})$, leucine $(6.6 / 100 \mathrm{~g})$, lysine $(5.7 / 100 \mathrm{~g})$, methionine $(2.7 / 100 \mathrm{~g})$, phenylalanine $(5.2 / 100 \mathrm{~g})$, threonine $(3.1 / 100 \mathrm{~g})$, tryptophan $(0.85 / 100 \mathrm{~g})$, and valine $(4.3 / 100 \mathrm{~g})$.

The amino acid showing the lowest percentage was termed as the first limiting amino acid in that protein.

\section{SDS-PAGE of Total Flour Proteins}

Defatted wheat flour $(50 \mathrm{mg})$ was weighed in $1.5-\mathrm{ml}$ sterile Eppendorf tubes and mixed directly with $1 \mathrm{ml}$ of $2 \times$ Laemmli sample buffer (solution of $\mathrm{pH} 6.8$ containing $62.5 \mathrm{mM}$ Tris$\mathrm{HCl}, 2 \% \mathrm{SDS}, 25 \%$ glycerol, $0.01 \%$ bromophenol blue, and $5 \%$ ß-mercaptoethanol). The tubes were vortexed for $2 \mathrm{~min}$ until all the flour was completely suspended, placed and allowed to mix properly in an orbital shaker (151 rpm) for $90 \mathrm{~min}$ at $45^{\circ} \mathrm{C}$. The tubes containing the suspended flour were heated at $100^{\circ} \mathrm{C}$ for $5 \mathrm{~min}$ and centrifuged at $12,000 \times g$ for $15 \mathrm{~min}$ (RC 4815S, Eltek, Mumbai, India). Of the supernatant, 10 $\mu \mathrm{l}$ was loaded in each cell (Mini-Protean Tetra Cell, BioRad Laboratories, Hercules, CA, USA). Proteins were separated using $4 \%$ stacking gel and $12 \%$ resolving gel. Gels were run at $25 \mathrm{~mA}$ until the tracking dye reached the bottom of the well, 
removed and stained. The gels were stained overnight with $0.1 \%$ Coomassie Brilliant Blue-R250 dissolved in 40\% methanol and $10 \%$ acetic acid. Destaining was performed using 25\% methanol and $10 \%$ acetic acid. The molecular weights of the polypeptides were estimated using a broad-range molecular weight standard (GeNei, Bangalore, India): myosin $(205 \mathrm{kDa})$, phosphorylase B $(97.4 \mathrm{kDa})$, bovine serum albumin $(66.0 \mathrm{kDa})$, ovalbumin $(44.0$ $\mathrm{kDa})$, carbonic anhydrase $(29.00 \mathrm{kDa})$, soybean trypsin inhibitor $(20.10 \mathrm{kDa})$, lysozyme $(14.30 \mathrm{kDa})$, aprotinin $(6.50 \mathrm{kDa})$, and insulin $(3.50 \mathrm{kDa})$. The destained gels were quantified using a Bio-Rad EZ imager (Bio-Rad Laboratories, Hercules, CA, USA). Classification of the total flour proteins was done according to DuPont et al. (25). The band percentage of each band was determined after the intensity of all the bands in a particular lane was set at $100 \%$. The proportion of the different flour proteins in wheat cultivars was calculated from the area of their subunits relative to the total extractable proteins. SDS-PAGE gels were run in duplicate simultaneously using aliquots of the same sample.

\section{Statistical Analysis}

Data were expressed in terms of mean \pm SD. One-way analysis of variance (ANOVA) was used and comparison of means was done using Tukey's post-hoc test (Minitab version 17, Minitab Inc., State College, PA, USA). Means were considered significantly different at $p \leq 0.05$. In order to determine the relationship between the different parameters, Pearson's correlation coefficient (significance levels at $p<0.05$ and $p<$ 0.01 ) was performed using SPSS version 16.0 (SPSS Inc., Chicago, IL, USA).

\section{RESULTS AND DISCUSSION Grain Characteristics}

The various physical parameters of the wheat grains are given in Table 1. The moisture content of the grains varied significantly ( $p \leq 0.05$ ), being highest for PBW-660 (8.54\%) and lowest for HD-2851 (4.81\%). The grain length of the different wheat varieties varied between 6.29 and $7.30 \mathrm{~mm}$ and was found to be maximum for SW-2 and least for HD-2967. The breadth varied from $3.19 \mathrm{~mm}$ in SW to $13.55 \mathrm{~mm}$ in PBW-175. Thickness varied from 2.82 to $3.39 \mathrm{~mm}$ and was highest for HD-2851 and lowest for PBW-660 and WH-1105. The length and breadth $(L / B)$ ratio was highest for wheat variety SW-2 (2.15) and lowest for wheat variety HD-2967 (1.78). Know-how of the length, breadth, and thickness of seeds is important in determining/regulating the aperture sizes in the machines used for the handling of grains. The length of the seed provides an indication of its natural rest position and helps in the application of compressive force, resulting in seed coat rupture with minimal damage to the kernel (5). The equivalent diameter varied significantly $(p \leq 0.05)$ and was highest for the wheat variety SW-2 $(4.29 \mathrm{~mm})$ and lowest for $\mathrm{WH}-1105(4.01 \mathrm{~mm})$. The equivalent diameter helps in the rough estimation of the flowing properties of the grain in the stream of air, which in turn helps during cleaning in the separation of foreign materials by pneumatic means (5).

Shape is important for the separation of foreign materials, grading, quality evaluation, and heat and mass transfer

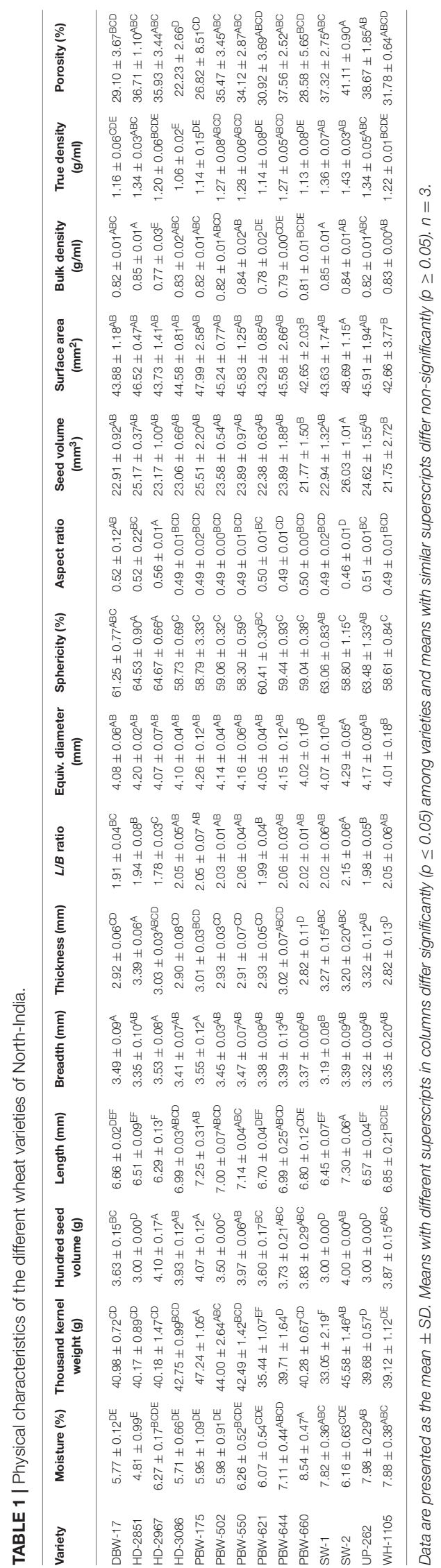


calculations. The shape is usually expressed in terms of sphericity and aspect ratio (4) for particular food materials. Sphericity measures how much resemblance an object has to that of a perfect sphere of the same volume. The sphericity of the wheat varieties varied significantly and ranged from 58.30 to $64.67 \%$. Wheat variety PBW-550 showed the lowest value for sphericity; the highest value was observed in HD-2967. The sphericity values of the wheat seeds indicate that these seeds are more elongated and may slide rather than roll out, which becomes an important factor for the design of hoppers, dehullers (5), and other processing instruments. The aspect ratio relates the width to the length and is an indication of the oblong shape of the seed (5). Among the wheat varieties, HD-2967 had the highest aspect ratio of 0.56 and SW-2 had the lowest value of 0.46 . The seed volume and surface area were observed in ranges of $21.75-26.03$ and $42.65-48.69$ $\mathrm{mm}^{2}$, respectively, and varied significantly $(p \leq 0.05)$ among the wheat cultivars. SW-2 had the highest and WH-1105 had the lowest value for seed volume. The surface area was highest for SW-2 and lowest for PBW-660.

The bulk and true density of the wheat varieties varied from 0.77 to $0.85 \mathrm{~g} / \mathrm{ml}$ and from 1.06 to $1.43 \mathrm{~g} / \mathrm{ml}$, respectively (Table 1). Significant $(p \leq 0.05)$ differences were observed in the bulk and true density of the wheat varieties. The highest bulk density was observed in wheat varieties HD-2851 and SW-1 and lowest in HD-2967. Among the wheat varieties, SW-2 showed the highest and HD-3086 showed the lowest value of true density. Knowledge of the density of the seeds is useful in estimating the yield of the product, quality, output from machines, and also in the transportation of seeds $(4,5)$.

Porosity values are helpful in the packaging, storage, aeration, and in the system design of various mass and heat transfer processes like drying, frying, heating, baking, extrusion, and cooling $(4,6)$. The porosity of the wheat varieties ranged from 22.23 to $41.11 \%$, which showed a significant $(p \leq 0.05)$ difference and was highest for SW-2 (41.11\%) and lowest for HD-3086 (22.23\%). High porosity values are associated with better aeration and high water vapor permeability during processes like drying, frying, heating, baking, extrusion, and cooling (26).

Hundred seed volume varied significantly $(p \leq 0.05)$ from 3.00 to $4.10 \mathrm{ml}$ among the cultivars (Table 1). HD-2967 showed the highest whereas SW-1 and UP-262 showed the lowest value for hundred seed volume. Thousand kernel weight (TKW) showed a significant $(p \leq 0.05)$ difference among the wheat cultivars. TKW ranged from $33.05 \mathrm{~g}$ for SW1 and $47.24 \mathrm{~g}$ for wheat variety PBW-175. TKW is important for estimating the milling yield and grain quality; longer, round, and sound grains have higher TKW. The wheat grains used in this study were from a small to a large category based on the classification of Williams et al. (27), who classified wheat kernels based on grain weight (TKW) as $15-25 \mathrm{~g}$ (very small), 26-35 g (small), 36-45 g (medium), 46-55 g (large), and over $55 \mathrm{~g}$ (very large).

Earlier, Baljeet et al. (28) reported on the lengths of Indian wheat varieties in the range of $6.47-7.07 \mathrm{~mm}$, widths $3.0-3.50 \mathrm{~mm}$, thicknesses $2.10-2.60 \mathrm{~mm}, L / B$ ratios $2.02-2.15$, equivalent diameters $3.50-4.00 \mathrm{~mm}$, sphericity $53.59-60.14 \%$, surface areas $31.46-40.69 \mathrm{~mm}^{2}$, grain volumes $23.26-34.26$ $\mathrm{mm}^{3}$, porosity $33.52-39.54 \%$, and thousand kernel weights of
$34.81-47.47 \mathrm{~g}$. Our results are in close proximity to those of the reported study; however, the slight variations between the two studies might be due to differences in the cultivars used, and to some extent, the agronomic practices followed.

\section{Grain Color}

Grain color of wheat varieties evaluated in terms of CIE (International Commission on Illumination) color values $\left(L^{*}\right.$, $a^{*}$, and $b^{*}$ ) showed varietal difference and is summarized in Table 2. $L^{*}$, which indicates lightness ( 0 is black and 100 is white), was observed in the range of 57.43-61.38. Statistical analysis revealed a significant $(p \leq 0.05)$ difference in $L^{*}$ among the wheat cultivars. The highest $L^{*}$ was observed in wheat cultivar HD-2967 and the lowest in HD-2851. The higher $L^{*}$ of HD-2967 indicated its lighter color as compared to the other wheat varieties. The CIE $a^{*}$ values ranged from 6.06 to 7.26 and varied significantly $(p \leq 0.05)$ among the different cultivars. Wheat variety PBW660 showed the highest value for $a^{*}$, and the lowest value was observed in WH-1105. Positive $a^{*}$ values indicate a red tint among the different wheat varieties. The $b^{*}$ value was highest in the wheat variety PBW-502 (20.24) and lowest for HD-2851 (17.78), thus giving an indication of a more yellow color. The chroma values showed a similar pattern to the $b^{*}$ values and varied significantly $(p \leq 0.05)$ from 18.82 to 21.37 . Hue values showed a significant $(p \leq 0.05)$ difference among the different wheat cultivars and ranged from 69.49 (for SW-1) to 72.57 (for UP-262). Previous studies have reported $L^{*}$ values of 35.2-58.9, $a^{*}$ of 1.2-10.1, $b^{*}$ of 11.5-27.4, chroma of 12.6-28.6, and hue values of 58.8-85.0 for wheat cultivars (29). $\Delta E$, which measures the total color difference, varied from 60.43 to 64.89 and followed the same pattern as $L^{*}$.

The color in the wheat varieties is due to various pigments like carotenoids, flavonoids, anthocyanins, and some phenolic compounds (30), and the distribution of these compounds is affected by the genetic makeup of the cultivars, the geographical location, climate, and soil, which in turn results in color variations in wheat varieties (7). New breeding programs aimed at increasing the concentrations of these colored bioactive compounds in wheat and its products without affecting the yield can result in foods with superior bioactive and functional properties $(7,29)$.

\section{Flour Characteristics Proximate Composition}

The proximate composition of the different wheat varieties grown under different geographical conditions is given in Table 3. Moisture content varied from 8.67 to $12.65 \%$. The protein content in the flour of the different wheat varieties varied from 9.32 to $12.60 \%$. The protein content was found to be significantly $(p \leq 0.05)$ highest in the wheat variety HD-2967 and lowest in SW-1. Fat content was observed in the range between 0.91 and $1.51 \%$. Ash content varied from 0.41 to $1.08 \%$. Crude fiber ranged from 0.08 to $0.26 \%$. The carbohydrate content, calculated after subtracting the values of moisture, fat, protein, ash, and fiber, ranged from 72.23 to $79.35 \%$ and was highest for SW-1 and lowest for HD-2967. Energy values ranged from 352.23 to $368.11 \mathrm{kcal} / 100 \mathrm{~g}$. Significant differences $(p \leq 0.05)$ 
TABLE 2 | CIE color parameters of the grains and flours of the different wheat varieties of North-India.

\begin{tabular}{|c|c|c|c|c|c|c|c|c|c|c|c|c|}
\hline \multirow[t]{2}{*}{ Variety } & \multicolumn{6}{|c|}{ Wheat kernel } & \multicolumn{6}{|c|}{ Wheat flour } \\
\hline & $L^{*}$ & $a^{*}$ & $b^{*}$ & $\Delta E$ & Chroma & Hue & $L^{*}$ & $a^{*}$ & $b^{*}$ & $\Delta E$ & Hue & Chroma \\
\hline BW-17 & $.82 \pm 1.19^{\mathrm{ABC}}$ & $6.67 \pm 0.11^{\mathrm{BCD}}$ & $19.50 \pm 0.38^{A B C}$ & $62.32 \pm 1.25^{\mathrm{ABC}}$ & $20.61 \pm 0.39^{\mathrm{ABC}}$ & $71.11 \pm 0.13^{\mathrm{BC}}$ & $90.82 \pm 0.22^{C}$ & $0.48 \pm 0.03^{\mathrm{BCD}}$ & $10.52 \pm 0.18^{A}$ & $91.32 \pm 0.30^{C}$ & $87.39 \pm 0.12^{\mathrm{EF}}$ & $10.53 \pm 0.18^{A}$ \\
\hline HD-2851 & $57.43 \pm 0.37^{C}$ & $6.17 \pm 0.19^{\mathrm{CDE}}$ & $17.78 \pm 0.14^{\mathrm{D}}$ & $60.43 \pm 0.39^{C}$ & $18.82 \pm 0.16^{\mathrm{D}}$ & $70.86 \pm 0.51^{\mathrm{BCD}}$ & $92.35 \pm 0.14^{\mathrm{AB}}$ & $0.22 \pm 0.04^{G}$ & $8.49 \pm 0.16^{G}$ & $92.74 \pm 0.13^{\mathrm{AB}}$ & $88.54 \pm 0.21^{\mathrm{A}}$ & $8.49 \pm 0.16^{G}$ \\
\hline HD-2967 & $61.38 \pm 1.82^{\mathrm{A}}$ & $6.80 \pm 0.20^{\mathrm{AB}}$ & $19.92 \pm 0.86^{\mathrm{AB}}$ & $64.89 \pm 1.98^{\mathrm{A}}$ & $21.05 \pm 0.82^{\mathrm{AB}}$ & $71.12 \pm 0.88^{\mathrm{BC}}$ & $91.72 \pm 0.27^{\mathrm{BC}}$ & $0.47 \pm 0.03^{\mathrm{BCD}}$ & $9.64 \pm 0.11^{C}$ & $92.22 \pm 0.26^{\mathrm{ABC}}$ & $87.19 \pm 0.16^{\mathrm{EFG}}$ & $9.66 \pm 0.11^{c}$ \\
\hline HD-3086 & $58.34 \pm 0.59^{\mathrm{BC}}$ & $6.68 \pm 0.24^{\mathrm{BCD}}$ & $18.73 \pm 0.39^{\mathrm{BCD}}$ & $61.63 \pm 0.56^{\mathrm{BC}}$ & $19.88 \pm 0.44^{\mathrm{BCD}}$ & $70.38 \pm 0.37^{\mathrm{CD}}$ & $92.59 \pm 1.01^{\mathrm{AB}}$ & $0.28 \pm 0.05^{F G}$ & $7.71 \pm 0.07^{\mathrm{H}}$ & $92.90 \pm 1.01^{\mathrm{AB}}$ & $87.94 \pm 0.36^{\mathrm{BCD}}$ & $7.71 \pm 0.07^{\mathrm{H}}$ \\
\hline PBW-175 & $59.56 \pm 1.03^{\mathrm{ABC}}$ & $6.56 \pm 0.09^{B C D E}$ & $18.84 \pm 0.27^{\mathrm{BCD}}$ & $62.82 \pm 1.05^{\mathrm{ABC}}$ & $19.95 \pm 0.23^{\mathrm{BCD}}$ & $70.79 \pm 0.43^{\mathrm{BCD}}$ & $91.70 \pm 0.09^{\mathrm{BC}}$ & $0.41 \pm 0.04^{\mathrm{CDE}}$ & $9.38 \pm 0.14^{\mathrm{CD}}$ & $92.18 \pm 0.08^{\mathrm{BC}}$ & $87.52 \pm 0.19^{D E F}$ & $9.39 \pm 0.15^{\mathrm{CD}}$ \\
\hline PBW-502 & $60.87 \pm 0.98^{\mathrm{AB}}$ & $6.85 \pm 0.29^{A B}$ & $20.24 \pm 0.34^{A}$ & $64.51 \pm 0.80^{\mathrm{AB}}$ & $21.37 \pm 0.41^{\mathrm{A}}$ & $71.32 \pm 0.47^{\mathrm{ABC}}$ & $92.88 \pm 0.06^{A}$ & $0.28 \pm 0.01^{F G}$ & $8.65 \pm 0.12^{\mathrm{FG}}$ & $93.29 \pm 0.08^{A}$ & $88.15 \pm 0.07^{\mathrm{ABC}}$ & $8.65 \pm 0.12^{\mathrm{FG}}$ \\
\hline PBW-550 & $59.82 \pm 0.99^{A B C}$ & $6.61 \pm 0.09^{\mathrm{BCDE}}$ & $19.48 \pm 0.41^{\mathrm{ABC}}$ & $63.25 \pm 1.06^{\mathrm{ABC}}$ & $20.57 \pm 0.42^{\mathrm{ABC}}$ & $71.26 \pm 0.16^{\mathrm{ABC}}$ & $92.14 \pm 0.58^{\mathrm{AB}}$ & $0.40 \pm 0.03^{\mathrm{DE}}$ & $8.74 \pm 0.08^{\mathrm{FG}}$ & $92.56 \pm 0.57^{\mathrm{AB}}$ & $87.40 \pm 0.17^{\mathrm{DEF}}$ & $8.75 \pm 0.08^{F G}$ \\
\hline PBW-621 & $59.66 \pm 0.94^{\mathrm{ABC}}$ & $6.71 \pm 0.22^{\mathrm{ABC}}$ & $19.24 \pm 0.45^{\mathrm{ABC}}$ & $63.05 \pm 1.03^{\mathrm{ABC}}$ & $20.38 \pm 0.50^{A B C}$ & $70.79 \pm 0.18^{\mathrm{BCD}}$ & $92.02 \pm 0.24^{\mathrm{AB}}$ & $0.54 \pm 0.02^{\mathrm{AB}}$ & $9.20 \pm 0.06^{\mathrm{DE}}$ & $92.48 \pm 0.24^{\mathrm{AB}}$ & $86.66 \pm 0.11^{\mathrm{GH}}$ & $9.22 \pm 0.06^{\mathrm{DE}}$ \\
\hline PBW-644 & $60.23 \pm 0.95^{\mathrm{ABC}}$ & $6.45 \pm 0.24^{\mathrm{BCDE}}$ & $18.91 \pm 0.56^{\mathrm{ABCD}}$ & $63.45 \pm 1.08^{\mathrm{AB}}$ & $19.98 \pm 0.60^{A B C D}$ & $71.16 \pm 0.32^{\mathrm{BC}}$ & $91.70 \pm 0.14^{\mathrm{BC}}$ & $0.46 \pm 0.02^{\mathrm{BCD}}$ & $8.92 \pm 0.03^{\mathrm{EF}}$ & $92.14 \pm 0.15^{\mathrm{BC}}$ & $87.05 \pm 0.12^{\mathrm{FGH}}$ & $8.93 \pm 0.03^{\mathrm{EF}}$ \\
\hline PBW-66 & $59.41 \pm 0.48^{\mathrm{ABC}}$ & & $19.65 \pm 0.18^{\mathrm{ABC}}$ & $63.00 \pm 0.52^{A B C}$ & $20.95 \pm 0.21^{\mathrm{ABC}}$ & & & $0.49 \pm 0.01^{A B C}$ & $10.11 \pm 0.06^{B}$ & $92.74 \pm 0.08^{\mathrm{AB}}$ & $87.21 \pm 0.04^{\mathrm{EFG}}$ & $10.13 \pm 0.06^{\mathrm{B}}$ \\
\hline SW-1 & $58.36 \pm 0.65^{\mathrm{BC}}$ & $6.93 \pm 0.15^{\mathrm{AB}}$ & $3.52 \pm 0.30^{C D}$ & $61.62 \pm 0.69^{\mathrm{BC}}$ & $19.77 \pm 0.26^{\mathrm{BCD}}$ & $69.49 \pm 0.62^{\mathrm{D}}$ & $92.23 \pm 0.35^{\mathrm{AB}}$ & $0.32 \pm 0.03^{\mathrm{EF}}$ & $10.80 \pm 0.08^{A}$ & $92.86 \pm 0.35^{\mathrm{AB}}$ & $88.30 \pm 0.16^{A B}$ & $10.80 \pm 0.08^{A}$ \\
\hline SW-2 & $59.20 \pm 0.62^{\mathrm{ABC}}$ & $6.66 \pm 0.16^{\mathrm{BCD}}$ & $18.49 \pm 0.26^{\mathrm{CD}}$ & $62.38 \pm 0.66^{\mathrm{ABC}}$ & $19.66 \pm 0.21^{\mathrm{BCD}}$ & $70.19 \pm 0.66^{\mathrm{CD}}$ & $91.77 \pm 0.21^{\mathrm{BC}}$ & $0.40 \pm 0.03^{\mathrm{DE}}$ & $9.55 \pm 0.11^{C}$ & $92.27 \pm 0.2 \mathrm{O}^{\mathrm{ABC}}$ & $87.60 \pm 0.18^{\mathrm{CDE}}$ & $9.56 \pm 0.11^{C}$ \\
\hline UP-262 & $59.92 \pm 1.12^{\mathrm{ABC}}$ & $6.13 \pm 0.08^{\mathrm{DE}}$ & $19.53 \pm 0.58^{\mathrm{ABC}}$ & $63.32 \pm 1.22^{\mathrm{ABC}}$ & $20.47 \pm 0.56^{\mathrm{ABC}}$ & $72.57 \pm 0.53^{\mathrm{A}}$ & $92.08 \pm 0.20^{A B}$ & $0.57 \pm 0.04^{\mathrm{A}}$ & $9.41 \pm 0.05^{C D}$ & $92.56 \pm 0.20^{\mathrm{AB}}$ & $86.51 \pm 0.25^{\mathrm{H}}$ & $9.42 \pm 0.05^{C D}$ \\
\hline 1105 & $8.82 \pm 0.43^{\mathrm{ABC}}$ & $6.06 \pm 0.30^{\mathrm{E}}$ & $18.65 \pm 0.71^{\mathrm{BCD}}$ & $62.01 \pm 0.22^{\mathrm{ABC}}$ & $19.61 \pm 0.76^{C D}$ & $72.02 \pm 0.31^{A B}$ & $92.54 \pm 0.12^{\mathrm{AB}}$ & $0.26 \pm 0.03^{\mathrm{FG}}$ & $8.52 \pm 0.10^{G}$ & $92.93 \pm 0.12^{\mathrm{AB}}$ & $88.28 \pm 0.20^{A B}$ & $8.52 \pm 0.10^{G}$ \\
\hline
\end{tabular}

Data are presented as the mean $\pm S D$. Means with different superscripts in column differ significantly $(p \leq 0.05) . n=3$.

TABLE 3 | Proximate composition, wet and dry gluten, and SDS volume of flours of the different wheat varieties of North-India.

\begin{tabular}{|c|c|c|c|c|c|c|c|c|c|c|}
\hline Variety & Moisture (\%) & Protein (\%) & Fat $(\%)$ & Ash (\%) & Fiber (\%) & Carbohydrate (\%) & Energy (kcal/100 g) & Wet gluten (\%) & Dry gluten (\%) & $\begin{array}{l}\text { SDS sedimentation } \\
\text { volume }(\mathrm{ml})\end{array}$ \\
\hline DBW-17 & $10.12 \pm 1.13^{\mathrm{CDE}}$ & $12.10 \pm 0.59^{\mathrm{AB}}$ & $0.93 \pm 0.03^{\mathrm{EF}}$ & $1.08 \pm 0.04^{\mathrm{A}}$ & $0.15 \pm 0.07^{\mathrm{A}}$ & $75.62 \pm 1.62^{\mathrm{B}}$ & $359.25 \pm 4.58^{\mathrm{BCDE}}$ & $32.80 \pm 0.80^{\mathrm{EF}}$ & $12.23 \pm 0.10^{C}$ & $40.50 \pm 0.71^{\mathrm{BCD}}$ \\
\hline HD-2851 & $11.01 \pm 0.22^{\mathrm{BCD}}$ & $10.71 \pm 1.11^{\mathrm{ABCD}}$ & $1.05 \pm 0.16^{\mathrm{CDEF}}$ & $0.48 \pm 0.03^{\mathrm{EF}}$ & $0.11 \pm 0.01^{\mathrm{A}}$ & $76.64 \pm 1.28^{\mathrm{AB}}$ & $358.83 \pm 1.05^{\mathrm{BCDE}}$ & $26.49 \pm 0.73^{G}$ & $9.87 \pm 0.12^{\mathrm{D}}$ & $44.00 \pm 1.41^{\mathrm{ABC}}$ \\
\hline HD-2967 & $12.65 \pm 0.10^{A}$ & $12.60 \pm 0.66^{A}$ & $1.43 \pm 0.10^{\mathrm{AB}}$ & $0.89 \pm 0.04^{B}$ & $0.20 \pm 0.08^{A}$ & $72.23 \pm 0.74^{C}$ & $352.23 \pm 1.12^{\mathrm{E}}$ & $38.09 \pm 0.18^{B}$ & $13.34 \pm 0.18^{\mathrm{ABC}}$ & $49.00 \pm 0.00^{A}$ \\
\hline HD-3086 & $10.18 \pm 0.10^{\mathrm{CDE}}$ & $11.24 \pm 0.83^{\mathrm{ABC}}$ & $1.22 \pm 0.02^{\mathrm{ABCDEF}}$ & $0.66 \pm 0.03^{\mathrm{D}}$ & $0.20 \pm 0.02^{A}$ & $76.50 \pm 0.91^{A B}$ & $361.90 \pm 0.45^{\mathrm{ABC}}$ & $37.38 \pm 1.17^{\mathrm{BC}}$ & $13.58 \pm 0.38^{\mathrm{ABC}}$ & $45.00 \pm 0.00^{A B}$ \\
\hline PBW-175 & $10.54 \pm 0.66^{\mathrm{CD}}$ & $11.19 \pm 0.70^{\mathrm{ABCD}}$ & $0.93 \pm 0.05^{\mathrm{DEF}}$ & $0.71 \pm 0.07^{\mathrm{CD}}$ & $0.10 \pm 0.05^{A}$ & $76.56 \pm 1.35^{\mathrm{AB}}$ & $359.40 \pm 3.03^{\mathrm{BCDE}}$ & $38.17 \pm 0.68^{\mathrm{B}}$ & $14.24 \pm 0.18^{\mathrm{AB}}$ & $34.50 \pm 0.71^{D}$ \\
\hline PBW-502 & $10.23 \pm 0.23^{\mathrm{CDE}}$ & $11.81 \pm 0.19^{A B}$ & $1.12 \pm 0.15^{\mathrm{BCDEF}}$ & $0.71 \pm 0.03^{C D}$ & $0.15 \pm 0.03^{A}$ & $75.98 \pm 0.19^{B}$ & $361.26 \pm 1.75^{\mathrm{ABCD}}$ & $32.07 \pm 1.24^{\mathrm{EF}}$ & $12.06 \pm 0.37^{C}$ & $41.50 \pm 3.54^{\mathrm{BCD}}$ \\
\hline PBW-550 & $12.15 \pm 0.10^{A B}$ & $10.45 \pm 0.25^{\mathrm{BCD}}$ & $1.28 \pm 0.10^{\mathrm{ABCD}}$ & $0.63 \pm 0.04^{\mathrm{D}}$ & $0.25 \pm 0.07^{\mathrm{A}}$ & $75.25 \pm 0.15^{\mathrm{B}}$ & $354.28 \pm 0.24^{\mathrm{DE}}$ & $30.68 \pm 0.68^{F}$ & $12.17 \pm 0.38^{C}$ & $38.00 \pm 1.41^{\mathrm{BCD}}$ \\
\hline PBW-621 & $10.31 \pm 0.09^{C D}$ & $10.98 \pm 0.22^{\mathrm{ABCD}}$ & $1.22 \pm 0.19^{A B C D E F}$ & $0.81 \pm 0.06^{\mathrm{BC}}$ & $0.26 \pm 0.09^{A}$ & $76.42 \pm 0.13^{\mathrm{B}}$ & $360.57 \pm 1.02^{\mathrm{BCD}}$ & $33.53 \pm 0.38^{\mathrm{DEF}}$ & $12.30 \pm 2.01^{C}$ & $40.00 \pm 2.83^{\mathrm{BCD}}$ \\
\hline PBW-644 & $10.22 \pm 0.15^{\mathrm{CDE}}$ & $11.71 \pm 0.38^{\mathrm{ABC}}$ & $1.51 \pm 0.04^{\mathrm{A}}$ & $0.84 \pm 0.02^{\mathrm{B}}$ & $0.24 \pm 0.12^{A}$ & $75.47 \pm 0.30^{\mathrm{B}}$ & $362.34 \pm 0.42^{\mathrm{ABC}}$ & $43.04 \pm 1.90^{\mathrm{A}}$ & $15.00 \pm 0.23^{A}$ & $37.50 \pm 0.70^{C D}$ \\
\hline PBW-660 & $10.45 \pm 0.31^{C D}$ & $11.09 \pm 0.59^{\mathrm{ABCD}}$ & $1.38 \pm 0.26^{\mathrm{ABC}}$ & $0.60 \pm 0.04^{\mathrm{DE}}$ & $0.16 \pm 0.04^{\mathrm{A}}$ & $76.33 \pm 0.71^{B}$ & $362.03 \pm 2.32^{\mathrm{ABC}}$ & $26.76 \pm 0.150^{G}$ & $9.97 \pm 0.15^{\mathrm{D}}$ & $36.00 \pm 1.41^{\mathrm{D}}$ \\
\hline SW-1 & $9.61 \pm 0.18^{\mathrm{DE}}$ & $9.32 \pm 0.55^{\mathrm{D}}$ & $1.01 \pm 0.04^{\mathrm{DEF}}$ & $0.63 \pm 0.08^{\mathrm{D}}$ & $0.08 \pm 0.08^{A}$ & $79.35 \pm 0.54^{\mathrm{A}}$ & $363.77 \pm 0.49^{\mathrm{AB}}$ & $27.56 \pm 1.20^{G}$ & $9.63 \pm 0.24^{\mathrm{D}}$ & $39.50 \pm 2.12^{\mathrm{BCD}}$ \\
\hline sW-2 & $11.46 \pm 0.12^{\mathrm{ABC}}$ & $9.84 \pm 0.81^{C D}$ & $0.91 \pm 0.02^{\mathrm{F}}$ & $0.70 \pm 0.03^{\mathrm{CD}}$ & $0.16 \pm 0.07^{A}$ & $76.94 \pm 0.89 \mathrm{AB}$ & $355.29 \pm 0.34^{\mathrm{CDE}}$ & $23.46 \pm 0.68^{\mathrm{H}}$ & $8.28 \pm 0.10^{\mathrm{D}}$ & $44.00 \pm 0.00^{\mathrm{ABC}}$ \\
\hline UP-262 & $10.86 \pm 1.46^{\mathrm{BCD}}$ & $12.19 \pm 0.49^{A B}$ & $1.01 \pm 0.12^{\mathrm{DEF}}$ & $0.41 \pm 0.05^{\mathrm{F}}$ & $0.21 \pm 0.05^{A}$ & $75.32 \pm 1.79^{\mathrm{B}}$ & $359.19 \pm 6.13^{\mathrm{AB}}$ & $34.92 \pm 1.30^{\mathrm{CDE}}$ & $12.73 \pm 0.26^{\mathrm{BC}}$ & $37.50 \pm 0.71^{\mathrm{CD}}$ \\
\hline WH-1105 & $8.67 \pm 0.12^{\mathrm{E}}$ & $10.71 \pm 1.11^{\mathrm{ABCD}}$ & $1.27 \pm 0.05^{\mathrm{ABCDE}}$ & $0.67 \pm 0.04^{D}$ & $0.21 \pm 0.09^{A}$ & $77.84 \pm 0.59^{A B}$ & $368.11 \pm 1.21^{\mathrm{A}}$ & $36.23 \pm 1.39^{\mathrm{BCD}}$ & $13.36 \pm 0.10^{\mathrm{ABC}}$ & $49.50 \pm 3.54^{\mathrm{A}}$ \\
\hline
\end{tabular}

Data are presented as the mean $\pm S D$. Means with different superscripts in column differ significantly $(p \leq 0.05) . n=3$. 
were observed in the moisture, fat, ash, protein, carbohydrate, and energy values among the cultivars. Fiber content showed a non-significant $(p \geq 0.05)$ difference among the cultivars. Considerable variations in the protein content of flour among the varieties revealed that these varieties can be used for varied wheat-based products. Previous studies have reported a moisture content of $7.79-9.35 \%$, fat $2.62-3.48 \%$, protein $9.03-12.33 \%$, crude fiber $0.79-0.93 \%$, and carbohydrate content of $72.6-76.5 \%$ (31). Memon et al. (32) obtained a moisture content of 7.13$7.61 \%$, protein $10.9-11.8 \%$, fat $0.12-0.25 \%$, ash $2.10-2.77 \%$, crude fiber $0.26-0.28 \%$, carbohydrate $78.4-79.7 \%$, and energy $358.99-363 \mathrm{kcal} / 100 \mathrm{~g}$ for flour of different wheat varieties grown in Pakistan. The chemical composition is dependent on the genetic makeup of the cultivars, climatic variations, irrigation practices, milling, soil fertility, and agricultural practices, which might explain the difference among various studies.

\section{Dry and Wet Gluten Contents}

The wet and dry gluten content of the different wheat varieties is given in Table 3. Wet gluten provides a quantitative measurement of the gluten-forming proteins in flour that are primarily responsible for the rheological properties and baking qualities of its dough (33). Wet gluten varied from 23.46 to $43.04 \%$. The flour of the wheat variety PBW-644 recorded the significantly $(p \leq 0.05)$ highest wet gluten content and wheat variety SW-2 showed the lowest. The dry gluten content followed the same pattern as the wet gluten among the wheat varieties and varied from 8.28 to $15.00 \%$. The variations in the gluten contents among the different wheat varieties arose due to the genetic makeup, cultivation practices, and fertilizer application (34), which support the significant difference found in the present study. The present results are closely related to the previous findings of Kundu et al. (8) who reported wet and dry gluten contents of different Indian wheat varieties between 14.49 and $43.70 \%$ and between 5.12 and $12.82 \%$, respectively. However, lower values for wet and dry gluten contents (19.76-26.08 and $6.83-10.75 \%$, respectively) have been reported by Asim et al. (35) for different Pakistani wheat varieties.

\section{SDS Sedimentation Value}

SDS sedimentation provides information about the protein quality of the wheat flour and is used to predict the gluten strength and baking quality (36). The SDS sedimentation value of flours from the different wheat cultivars ranged from 34.50 to $49.50 \mathrm{ml}$ (Table 3). The flour of the wheat variety WH-1105 showed significantly the highest and PBW-175 the lowest SDS sedimentation value. The SDS sedimentation value has been reported to be due to the swelling of the glutenin strands (37), and dough with higher gluten strength results in higher swelling in the SDS solution, which results in higher sedimentation values. Wheat varieties having sedimentation values of $<30 \mathrm{ml}$ are more suitable for cookie making, $30-60 \mathrm{ml}$ for chapatti/pasta making, and those with $>60 \mathrm{ml}$ for bread making (38). Kundu et al. (8) also observed that a sedimentation value of $35.7 \mathrm{ml}$ resulted in good quality chapatti and that above $55 \mathrm{ml}$ leads to poor quality chapatti. The results confirmed that the wheat varieties used in this study showed variable gluten strength, more suitable for making chapattis, and are of comparatively poor quality for bread and biscuit making. Similar results were obtained by Patil et al. (38), who reported that Indian wheat varieties were more suitable for making good to very good chapattis. SDS sedimentation values of 33-52 $\mathrm{ml}$ have also been reported by Panghal et al. (39) for different Indian wheat varieties, which are in concordance with our findings.

\section{Flour Color}

The CIE $L^{*}, a^{*}$, and $b^{*}$ values of the flour from the different wheat varieties ranged from 90.82 to $92.88,0.22$ to 0.57 , and from 7.71 to 10.80 , respectively (Table 2 ). Significant $(p \leq 0.05)$ differences were observed in the color parameters $\left(L^{*}, a^{*}\right.$, and $\left.b^{*}\right)$ in the flour of the different wheat varieties. Flour of the wheat variety PBW-502 showed the highest and DBW-17 showed the lowest $L^{*}$ value. The highest $a^{*}$ value was reported for UP-262 flour, while HD-2851 flour showed the lowest value. Flour of the wheat variety SW-1 exhibited more yellowness in comparison to the other wheat varieties due to significantly ( $p$ $\leq 0.05$ ) higher $b^{*}$ values. On the contrary, flour of the wheat variety HD-3086 exhibited the lowest $b^{*}$ value. The results are in conformity with Costa et al. (40), who obtained $L^{*}, a^{*}$, and $b^{*}$ values of 92.94-95.42, 0.28-0.99, and 7.37-10.93 for flour of different Brazilian wheat genotypes. The color variations among flours of the different wheat varieties are mainly due to differences in the ash content, the contamination of flour with bran during milling, and, to some extent, the presence of naturally occurring pigments like anthocyanins, carotenoids, flavonoids, and some phenolic compounds (30), which are most concentrated in the aleurone layer and are removed during milling. The hue and chroma values varied significantly $(p \leq 0.05)$ from 86.51 to 88.54 and from 7.71 to 10.80 , respectively. Wheat variety HD-2967 showed the highest and UP-262 the lowest hue value. The highest value for chroma was observed in SW-1 and DBW-17 and the lowest in HD-3086. $\Delta E$, which is an indicator of total color difference, ranged from 91.32 to 93.29 for flours of the different wheat cultivars.

\section{Solvent Retention Capacity}

Solvent retention capacity (SRC) is the weight of the solvent retained by the wet, hydrated, and swollen flour pellets after centrifugation and is expressed as the percentage of flour weight. SRC is based on the principle of the swelling behavior of the different flour constituents in selected solvents: water (WSRC), lactic acid (LASRC), sodium carbonate (SCSRC), and sucrose (SUSRC) (41). SRC provides knowledge about the various chemical constituents of the flour during dough formation, its rheological properties, baking, and processing (21), which results in better finished product quality (22).

Table 4 lists the mean SRC values of the 14 Indian wheat varieties. LASRC mimics the acidic environment produced by lactic acid bacteria and characterizes the swelling of the glutenin fibrils of gluten proteins during fermentation, thus reflecting the dough strength. LASRC ranged from 80.45 to $113.70 \%$ and was found highest in the flour of wheat variety HD-3086 and lowest in the flour of UP-262, which reflected the high variability in gluten proteins among the wheat varieties. SCSRC, an indicator 
TABLE 4 | Solvent retention capacity (SRC) of flours of the different wheat varieties of North-India.

\begin{tabular}{|c|c|c|c|c|c|}
\hline Variety & Water (WSRC) & Sucrose (SUSRC) & Lactic acid (LASRC) & Sodium carbonate (SCSRC) & Gluten performance index (GPI) \\
\hline DBW-17 & $74.72 \pm 0.14^{\mathrm{DEFG}}$ & $107.78 \pm 3.18^{\mathrm{ABC}}$ & $90.08 \pm 0.20^{F}$ & $86.68 \pm 1.22^{\mathrm{CDE}}$ & $0.46 \pm 0.01^{F}$ \\
\hline HD-2851 & $75.62 \pm 0.75^{\mathrm{DEFG}}$ & $101.33 \pm 3.62^{C D}$ & $93.74 \pm 1.64^{\mathrm{EF}}$ & $87.36 \pm 2.32^{\mathrm{CDE}}$ & $0.50 \pm 0.01^{\mathrm{CDEF}}$ \\
\hline HD-2967 & $78.20 \pm 0.28^{\mathrm{BCDE}}$ & $103.22 \pm 3.05^{\mathrm{BCD}}$ & $105.92 \pm 2.84^{\mathrm{BC}}$ & $81.88 \pm 0.35^{\mathrm{E}}$ & $0.57 \pm 0.02^{A}$ \\
\hline HD-3086 & $78.23 \pm 0.95^{\mathrm{BCDE}}$ & $103.36 \pm 3.45^{\mathrm{BCD}}$ & $113.70 \pm 1.15^{\mathrm{A}}$ & $89.67 \pm 0.34^{\mathrm{BCD}}$ & $0.59 \pm 0.01^{A}$ \\
\hline PBW-175 & $82.65 \pm 0.54^{\mathrm{ABC}}$ & $111.80 \pm 0.00^{\mathrm{AB}}$ & $94.95 \pm 0.27^{\mathrm{EF}}$ & $91.25 \pm 0.07^{\mathrm{BCD}}$ & $0.47 \pm 0.00^{\mathrm{EF}}$ \\
\hline PBW-502 & $80.28 \pm 3.25^{\mathrm{BCD}}$ & $101.84 \pm 3.25^{C D}$ & $94.89 \pm 1.83^{\mathrm{EF}}$ & $91.87 \pm 2.44^{\mathrm{ABCD}}$ & $0.49 \pm 0.00^{\mathrm{DEF}}$ \\
\hline PBW-550 & $84.14 \pm 1.53^{\mathrm{AB}}$ & $114.61 \pm 3.75^{\mathrm{A}}$ & $110.88 \pm 1.67^{\mathrm{AB}}$ & $97.95 \pm 0.90^{\mathrm{A}}$ & $0.52 \pm 0.00^{\mathrm{BCD}}$ \\
\hline PBW-621 & $70.76 \pm 0.54^{F G}$ & $100.25 \pm 2.64^{\mathrm{CDE}}$ & $102.60 \pm 0.54^{C D}$ & $81.93 \pm 1.29^{\mathrm{E}}$ & $0.56 \pm 0.01^{\mathrm{AB}}$ \\
\hline PBW-644 & $74.28 \pm 2.91^{\mathrm{DEFG}}$ & $102.11 \pm 1.90^{\mathrm{BCD}}$ & $90.19 \pm 2.91^{F}$ & $85.21 \pm 1.02^{\mathrm{DE}}$ & $0.48 \pm 0.01^{\mathrm{DEF}}$ \\
\hline PBW-660 & $76.59 \pm 2.92^{\mathrm{CDEF}}$ & $100.55 \pm 1.55^{\mathrm{CDE}}$ & $93.78 \pm 2.24^{\mathrm{EF}}$ & $88.64 \pm 0.82^{\mathrm{BCD}}$ & $0.50 \pm 0.01^{\mathrm{DEF}}$ \\
\hline SW-1 & $87.53 \pm 2.56^{\mathrm{A}}$ & $98.71 \pm 1.55^{\mathrm{CDE}}$ & $99.33 \pm 2.83^{\mathrm{CDE}}$ & $95.29 \pm 0.34^{A B}$ & $0.51 \pm 0.02^{\mathrm{CDE}}$ \\
\hline SW-2 & $75.23 \pm 1.72^{\mathrm{DEFG}}$ & $90.87 \pm 0.48^{\mathrm{EF}}$ & $90.14 \pm 0.69^{F}$ & $93.29 \pm 2.68^{\mathrm{ABC}}$ & $0.49 \pm 0.00^{\mathrm{DEF}}$ \\
\hline UP-262 & $69.70 \pm 0.48^{G}$ & $85.37 \pm 1.64^{F}$ & $80.45 \pm 2.59^{G}$ & $81.22 \pm 3.82^{E}$ & $0.48 \pm 0.02^{\mathrm{DEF}}$ \\
\hline WH-1105 & $72.13 \pm 0.13^{\mathrm{EFG}}$ & $95.44 \pm 1.00^{\mathrm{DE}}$ & $95.86 \pm 0.27^{\mathrm{DEF}}$ & $80.98 \pm 0.27^{E}$ & $0.54 \pm 0.00^{\mathrm{ABC}}$ \\
\hline
\end{tabular}

Data are presented as the mean $\pm S D$. Means with different superscripts in column differ significantly $(p \leq 0.05)$. $n=3$.

of starch damage and, indirectly, hardness, was highest for PBW-550 (97.95\%) and lowest for WH-1105 (80.98\%). SUSRC, associated with gliadin characteristics and the swelling of wheat flour arabinoxylans (22), ranged from 85.37 to $114.61 \%$. PBW550 showed the highest and UP-262 the lowest SUSRC. Water hydrates and swells up all three (gluten, starch, and pentosans) polymeric flour components (22). WSRC ranged from 69.70 to 87.53\% and was found highest in UP-262 and lowest in SW1. Duyvejonck et al. (41) found that wheat varieties with high WSRC and LASRC resulted in poor cookie making.

The WSRC, LASRC, SCSRC, and SUSRC values were reported in ranges of $49.4-56.3,90-118.5,66-83.0$, and $86.4-106.3 \%$, respectively, for US soft wheat cultivars (42). Ram et al. (21) reported WSRC values of 53.4-70.6\%, LASRC of 72.0-122.8\%, SCSRC of $63.9-87.2 \%$, and SUSRC of 75.1-97.9\% across 192 Indian wheat varieties. So our results are within the range reported by these authors. However, higher SRC values have been reported by Lindgren and Simsek (43) for hard red spring wheat cultivars: WSRC of 69.6-104.9\%, LASRC of 148.5-178.1\%, SCSRC of $86.0-160.2 \%$, and SUSRC of 128.2-157.5\%. Similarly, high SRC values for different Pakistani wheat varieties have been reported by Pasha et al. (44) owing to their semi-soft to medium-hard nature. Higher SRC values are usually associated with better baking qualities (28). The low LASRC values indicated that the wheat varieties in the current study are in the soft to the semi-soft range, having medium-strong gluten, and are more suitable for making chapattis and biscuits. A similar observation regarding Indian wheat varieties has been made by Ram et al. (21). Karaduman (45) also reported LASRC as an effective, fast, and reliable method for differentiating between soft and hard wheat varieties. Hammed et al. (46) also reported higher SRC values for hard wheat varieties owing to their high protein content, greater gluten strength, greater starch damage, high arabinoxylan content, and high water absorption capacity.

Gluten performance index (GPI) provides the most reliable information about gluten strength, functionality, and baking performance and is considered a better predictor to determine the overall performance of flour glutenin (22). GPI ranged from 0.46 to 0.59 (Table 5$)$ and varied significantly $(p \leq 0.05)$ among flours of the different wheat cultivars. HD-3086 showed the highest GPI value of 0.46 and DBW-17 the lowest GPI value of 0.59 . Jeon et al. (42) reported GPI values of 0.52-0.69 for soft wheat cultivars. Our results are in close range with those reported. However, higher values have been reported by Lindgren and Simsek (43) (0.47-0.80) and Hammed et al. (46) (0.62-0.85) for hard wheat varieties. GPI is directly related to LASRC and can be detrimentally minimized with higher values of SUSRC and SCSRC. In our study, the values of LASRC, SUSRC, and SCSRC are almost the same, which might explain the observed values of GPI and also the type of wheat varieties used in this study.

\section{Amino Acid Composition of Wheat Varieties}

Figures S1A,B display the HPLC chromatogram of a standard mixture of 18 amino acids and flour of one of the wheat varieties, respectively. All the amino acids were separated within a run time of $<40 \mathrm{~min}$, having well-separated peaks. The retention time of the samples was comparable to that of the standard mixture.

The amino acid composition of the wheat varieties from different regions of North India is summarized in Tables 5, 6. The results indicated a considerable difference in the amount of amino acid among the wheat cultivars. Glutamic acid was found to be the most abundant amino acid, with mean concentrations of 30.53-37.18 g/100 g protein (Table 5). The highest concentration of glutamic acid was observed in the wheat variety PBW-550 and was lowest in UP-262. The results are inconsistent with those of Wang et al. (47), who found glutamic acid as the most dominant amino acid in the vicinity of $30.99-31.41 \mathrm{~g} / 100 \mathrm{~g}$ protein in a Chinese wheat variety. Jood et al. (48) also found glutamic acid as the predominant amino acid, having a concentration of $31 \mathrm{~g} / 100 \mathrm{~g}$ protein in an Indian wheat variety. Anjum et al. (15), however, reported glutamic acid contents of $6.29-12.03 \mathrm{~g} / 100 \mathrm{~g}$ 
TABLE 5 | Non-essential amino acid (NEAA) content in flours of the different wheat varieties of North-India (in grams per $100 \mathrm{~g}$ protein).

\begin{tabular}{|c|c|c|c|c|c|c|c|c|c|c|}
\hline Variety & Aspartic acid & Glutamic acid & Serine & Glycine & Alanine & Arginine & Tyrosine & Cystine & Proline & Total NEAA \\
\hline DBW-17 & $6.76 \pm 0.32^{A}$ & $31.99 \pm 1.15^{\mathrm{E}}$ & $4.23 \pm 0.29^{A}$ & $4.31 \pm 0.06^{\mathrm{H}}$ & $5.81 \pm 0.66^{\mathrm{BC}}$ & $2.27 \pm 0.07^{\mathrm{A}}$ & $3.20 \pm 0.02^{A}$ & $4.32 \pm 0.35^{\mathrm{A}}$ & $6.39 \pm 0.55^{\mathrm{DEF}}$ & $69.28 \pm 2.23^{\mathrm{BC}}$ \\
\hline HD-2851 & $3.63 \pm 0.35^{\mathrm{CDE}}$ & $32.27 \pm 0.26^{\mathrm{DE}}$ & $4.48 \pm 0.50^{\mathrm{A}}$ & $4.53 \pm 0.25^{\mathrm{H}}$ & $6.44 \pm 0.40^{\mathrm{BC}}$ & $2.10 \pm 0.29^{A}$ & $3.03 \pm 0.41^{\mathrm{A}}$ & $0.68 \pm 0.07^{\mathrm{B}}$ & $14.98 \pm 0.44^{\mathrm{A}}$ & $72.12 \pm 1.95^{\mathrm{ABC}}$ \\
\hline HD-2967 & $4.11 \pm 0.32^{\mathrm{BCDE}}$ & $33.90 \pm 0.12^{\mathrm{CD}}$ & $5.26 \pm 0.63^{A}$ & $4.64 \pm 0.20^{\mathrm{GH}}$ & $7.26 \pm 0.88^{\mathrm{ABC}}$ & $2.75 \pm 0.58^{A}$ & $3.72 \pm 0.70^{A}$ & $3.60 \pm 2.86^{A B}$ & $3.93 \pm 1.37^{F}$ & $69.17 \pm 0.80^{\mathrm{BC}}$ \\
\hline HD-3086 & $4.00 \pm 0.02^{\mathrm{CDE}}$ & $34.96 \pm 0.11^{\mathrm{BC}}$ & $5.11 \pm 0.29^{A}$ & $6.25 \pm 0.07^{\mathrm{ABCD}}$ & $7.03 \pm 0.16^{\mathrm{ABC}}$ & $2.71 \pm 0.36^{A}$ & $3.71 \pm 0.54^{\mathrm{A}}$ & $1.53 \pm 0.71^{\mathrm{AB}}$ & $5.99 \pm 1.22^{\mathrm{EF}}$ & $71.29 \pm 0.75^{A B C}$ \\
\hline PBW-175 & $4.90 \pm 0.16^{\mathrm{B}}$ & $36.84 \pm 0.27^{\mathrm{AB}}$ & $4.96 \pm 0.26^{A}$ & $5.51 \pm 0.39^{\mathrm{DEFG}}$ & $7.19 \pm 0.91^{\mathrm{ABC}}$ & $2.65 \pm 0.10^{A}$ & $3.90 \pm 0.11^{\mathrm{A}}$ & $1.29 \pm 0.12^{\mathrm{AB}}$ & $5.27 \pm 0.56^{\mathrm{EF}}$ & $72.50 \pm 0.76^{\mathrm{AB}}$ \\
\hline PBW-502 & $4.10 \pm 0.01^{\mathrm{BCDE}}$ & $34.40 \pm 0.45^{\mathrm{C}}$ & $4.17 \pm 0.46^{A}$ & $4.87 \pm 0.16^{\mathrm{FGH}}$ & $6.35 \pm 0.38^{\mathrm{BC}}$ & $2.54 \pm 0.34^{\mathrm{A}}$ & $3.84 \pm 0.51^{\mathrm{A}}$ & $0.73 \pm 0.08^{\mathrm{B}}$ & $9.05 \pm 0.60^{\mathrm{BCD}}$ & $70.05 \pm 1.46^{\mathrm{ABC}}$ \\
\hline PBW-550 & $4.10 \pm 0.19^{B C D E}$ & $37.18 \pm 0.85^{A}$ & $4.81 \pm 0.53^{A}$ & $6.60 \pm 0.52^{\mathrm{AB}}$ & $7.96 \pm 0.48^{\mathrm{AB}}$ & $2.85 \pm 0.05^{\mathrm{A}}$ & $3.87 \pm 0.30^{A}$ & $0.99 \pm 0.62^{\mathrm{B}}$ & $7.81 \pm 0.88^{\mathrm{CDE}}$ & $76.19 \pm 0.11^{\mathrm{A}}$ \\
\hline PBW-621 & $3.28 \pm 0.42^{\mathrm{E}}$ & $34.06 \pm 0.08^{C D}$ & $4.76 \pm 0.69^{A}$ & $5.17 \pm 0.27$ EFGH & $6.85 \pm 0.65^{\mathrm{ABC}}$ & $2.28 \pm 0.39^{A}$ & $3.13 \pm 0.52^{\mathrm{A}}$ & $0.77 \pm 0.11^{\mathrm{B}}$ & $7.91 \pm 0.25^{\mathrm{CDE}}$ & $68.19 \pm 2.88^{\mathrm{BC}}$ \\
\hline PBW-644 & $4.40 \pm 0.23^{\mathrm{BCD}}$ & $32.35 \pm 0.45^{\mathrm{DE}}$ & $4.56 \pm 0.08^{A}$ & $6.00 \pm 0.14^{\mathrm{BCDE}}$ & $6.15 \pm 0.48^{\mathrm{BC}}$ & $2.34 \pm 0.03^{A}$ & $3.43 \pm 0.26^{A}$ & $0.86 \pm 0.11^{\mathrm{B}}$ & $11.36 \pm 0.43^{\mathrm{B}}$ & $71.44 \pm 0.87^{\mathrm{ABC}}$ \\
\hline PBW-660 & $4.51 \pm 0.07^{\mathrm{BC}}$ & $34.62 \pm 0.36^{C D}$ & $4.37 \pm 0.18^{A}$ & $5.55 \pm 0.07^{\mathrm{CDEF}}$ & $8.70 \pm 0.28^{A}$ & $3.35 \pm 0.03^{A}$ & $3.99 \pm 0.18^{A}$ & $1.62 \pm 0.08^{\mathrm{AB}}$ & $5.61 \pm 0.38^{\mathrm{EF}}$ & $72.30 \pm 0.03^{\mathrm{ABC}}$ \\
\hline SW-1 & $3.72 \pm 0.07^{\mathrm{CDE}}$ & $30.83 \pm 0.71^{E}$ & $4.75 \pm 0.05^{A}$ & $5.98 \pm 0.11^{\mathrm{BCDE}}$ & $6.72 \pm 0.22^{\mathrm{ABC}}$ & $2.59 \pm 0.27^{\mathrm{A}}$ & $3.19 \pm 0.13^{\mathrm{A}}$ & $4.29 \pm 0.09^{A}$ & $7.94 \pm 0.39^{\mathrm{CDE}}$ & $70.00 \pm 0.79^{\mathrm{ABC}}$ \\
\hline SW-2 & $3.33 \pm 0.10^{\mathrm{E}}$ & $31.13 \pm 0.18^{\mathrm{E}}$ & $4.90 \pm 0.15^{\mathrm{A}}$ & $7.11 \pm 0.13^{A}$ & $5.62 \pm 0.44^{C}$ & $3.06 \pm 0.47^{\mathrm{A}}$ & $4.10 \pm 0.62^{A}$ & $0.83 \pm 0.10^{\mathrm{B}}$ & $5.78 \pm 0.27^{\mathrm{EF}}$ & $65.85 \pm 1.93^{C}$ \\
\hline UP-262 & $3.45 \pm 0.18^{\mathrm{E}}$ & $30.53 \pm 0.69^{E}$ & $4.40 \pm 0.43^{\mathrm{A}}$ & $6.43 \pm 0.11^{\mathrm{ABC}}$ & $5.88 \pm 0.50^{\mathrm{BC}}$ & $2.31 \pm 0.37^{\mathrm{A}}$ & $3.16 \pm 0.50^{A}$ & $0.76 \pm 0.38^{\mathrm{B}}$ & $11.94 \pm 1.27^{\mathrm{B}}$ & $68.87 \pm 3.28^{\mathrm{BC}}$ \\
\hline WH-1105 & $3.55 \pm 0.15^{\mathrm{DE}}$ & $31.10 \pm 0.22^{\mathrm{E}}$ & $5.18 \pm 0.12^{\mathrm{A}}$ & $6.78 \pm 0.14^{\mathrm{AB}}$ & $6.72 \pm 0.58^{\mathrm{ABC}}$ & $2.64 \pm 0.43^{\mathrm{A}}$ & $3.13 \pm 0.50^{\mathrm{A}}$ & $0.74 \pm 0.10^{\mathrm{B}}$ & $9.65 \pm 0.39^{\mathrm{BC}}$ & $69.50 \pm 1.15^{\mathrm{BC}}$ \\
\hline
\end{tabular}

Data are presented as the mean $\pm S D$. Means with different superscripts in column differ significantly $(p \leq 0.05)$ between varieties and means with similar superscripts differ non-significantly $(p \geq 0.05)$. $n=3$ for each treatment.

TABLE 6 | Essential amino acid (EAA) contents in flours of the different wheat varieties of North-India (in grams/100g protein).

\begin{tabular}{|c|c|c|c|c|c|c|c|c|c|}
\hline Name & Threonine & Histidine & Valine & Methionine & Phenylalanine & Isoleucine & Leucine & Lysine & Total EAA \\
\hline DBW-17 & $1.55 \pm 0.09^{A B C}$ & $1.40 \pm 0.07^{\mathrm{ABC}}$ & $2.28 \pm 0.13^{\mathrm{ABCD}}$ & $1.35 \pm 0.17^{\mathrm{BC}}$ & $5.05 \pm 0.10^{\mathrm{AB}}$ & $3.30 \pm 0.09^{A}$ & $7.11 \pm 0.66^{\mathrm{AB}}$ & $1.62 \pm 0.04^{\mathrm{EF}}$ & $23.67 \pm 0.95^{A}$ \\
\hline HD-2851 & $0.94 \pm 0.18^{C}$ & $0.87 \pm 0.18^{C}$ & $1.32 \pm 0.10^{\mathrm{CDE}}$ & $1.84 \pm 0.21^{\mathrm{ABC}}$ & $3.79 \pm 0.27^{\mathrm{AB}}$ & $3.04 \pm 0.21^{A}$ & $8.32 \pm 0.06^{\mathrm{AB}}$ & $3.61 \pm 0.37^{A}$ & $23.71 \pm 0.80^{A}$ \\
\hline HD-2967 & $1.54 \pm 0.07 \mathrm{ABC}$ & $1.33 \pm 0.24^{\mathrm{ABC}}$ & $1.65 \pm 1.03^{\mathrm{BCDE}}$ & $1.58 \pm 0.52^{\mathrm{ABC}}$ & $4.39 \pm 1.68^{\mathrm{AB}}$ & $3.27 \pm 0.08^{A}$ & $8.68 \pm 1.08^{\mathrm{AB}}$ & $1.27 \pm 0.09^{F}$ & $23.71 \pm 1.42^{\mathrm{A}}$ \\
\hline HD-3086 & $1.48 \pm 0.04 \mathrm{ABC}$ & $1.59 \pm 0.14^{\mathrm{ABC}}$ & $2.78 \pm 0.18^{\mathrm{AB}}$ & $1.52 \pm 0.05^{\mathrm{BC}}$ & $4.96 \pm 1.10^{\mathrm{AB}}$ & $3.37 \pm 0.35^{\mathrm{A}}$ & $8.79 \pm 0.37^{\mathrm{AB}}$ & $2.02 \pm 0.02^{\mathrm{BCDEF}}$ & $26.52 \pm 1.10^{A}$ \\
\hline PBW-175 & $1.96 \pm 0.03^{A}$ & $1.86 \pm 0.17^{\mathrm{A}}$ & $2.54 \pm 0.44^{\mathrm{ABCD}}$ & $1.19 \pm 0.37^{\mathrm{BC}}$ & $5.56 \pm 0.16^{A}$ & $3.77 \pm 0.30^{\mathrm{A}}$ & $8.68 \pm 0.49^{A B}$ & $1.57 \pm 0.18^{\mathrm{EF}}$ & $27.14 \pm 0.09^{A}$ \\
\hline PBW-502 & $1.28 \pm 0.24^{\mathrm{BC}}$ & $1.58 \pm 0.32^{\mathrm{ABC}}$ & $2.07 \pm 0.08^{\mathrm{BCDE}}$ & $0.82 \pm 0.43^{B C}$ & $3.45 \pm 0.33^{\mathrm{AB}}$ & $2.98 \pm 0.20^{\mathrm{A}}$ & $8.31 \pm 0.57^{\mathrm{AB}}$ & $3.38 \pm 0.67^{\mathrm{AB}}$ & $23.86 \pm 1.50^{\mathrm{A}}$ \\
\hline PBW-550 & $1.00 \pm 0.01^{\mathrm{C}}$ & $1.33 \pm 0.33^{A B C}$ & $2.68 \pm 0.20^{\mathrm{ABC}}$ & $0.57 \pm 0.25^{\mathrm{C}}$ & $3.87 \pm 0.16^{\mathrm{AB}}$ & $3.32 \pm 0.51^{\mathrm{A}}$ & $9.06 \pm 0.37^{\mathrm{AB}}$ & $1.98 \pm 0.29^{\mathrm{CDEF}}$ & $23.80 \pm 0.13^{\mathrm{A}}$ \\
\hline PBW-621 & $1.51 \pm 0.24 \mathrm{ABC}$ & $1.18 \pm 0.08^{\mathrm{ABC}}$ & $3.52 \pm 0.39^{A}$ & $1.12 \pm 0.04^{\mathrm{BC}}$ & $3.36 \pm 0.14^{\mathrm{AB}}$ & $2.85 \pm 0.29^{A}$ & $7.87 \pm 0.77^{\mathrm{AB}}$ & $2.72 \pm 0.88^{A B C D E}$ & $24.12 \pm 1.92^{\mathrm{A}}$ \\
\hline PBW-644 & $1.41 \pm 0.25 \mathrm{ABC}$ & $1.04 \pm 0.09^{\mathrm{BC}}$ & $2.25 \pm 0.28^{\mathrm{ABCD}}$ & $1.61 \pm 0.21^{\mathrm{ABC}}$ & $4.47 \pm 0.27^{\mathrm{AB}}$ & $2.80 \pm 0.24^{\mathrm{A}}$ & $6.99 \pm 1.26^{\mathrm{AB}}$ & $3.33 \pm 0.11^{\mathrm{ABC}}$ & $23.91 \pm 0.53^{A}$ \\
\hline PBW-660 & $1.18 \pm 0.11^{\mathrm{BC}}$ & $1.00 \pm 0.02^{\mathrm{BC}}$ & $1.23 \pm 0.18^{\mathrm{DE}}$ & $1.03 \pm 0.11^{\mathrm{BC}}$ & $2.83 \pm 0.10^{B}$ & $2.74 \pm 0.08^{A}$ & $6.31 \pm 0.21^{B}$ & $2.84 \pm 0.2 \mathrm{O}^{\mathrm{ABCDE}}$ & $19.13 \pm 0.54^{\mathrm{B}}$ \\
\hline SW-1 & $1.64 \pm 0.200^{A B}$ & $1.78 \pm 0.29^{A B}$ & $2.38 \pm 0.03^{A B C D}$ & $2.14 \pm 0.35^{A B}$ & $5.32 \pm 0.54^{\mathrm{A}}$ & $3.22 \pm 0.10^{A}$ & $7.31 \pm 0.71^{\mathrm{AB}}$ & $1.87 \pm 0.16^{\mathrm{DEF}}$ & $25.66 \pm 0.95^{A}$ \\
\hline SW-2 & $1.40 \pm 0.04 \mathrm{ABC}$ & $1.24 \pm 0.15^{\mathrm{ABC}}$ & $1.90 \pm 0.11^{\mathrm{BCDE}}$ & $1.97 \pm 0.19^{A B}$ & $4.75 \pm 0.28^{\mathrm{AB}}$ & $3.65 \pm 0.32^{\mathrm{A}}$ & $9.30 \pm 0.43^{A}$ & $3.22 \pm 0.08^{\mathrm{ABCD}}$ & $27.43 \pm 0.02^{A}$ \\
\hline UP-262 & $1.40 \pm 0.24 \mathrm{ABC}$ & $1.08 \pm 0.25^{\mathrm{ABC}}$ & $0.82 \pm 0.11^{E}$ & $2.88 \pm 0.14^{A}$ & $4.57 \pm 0.24^{\mathrm{AB}}$ & $3.06 \pm 0.29^{A}$ & $7.97 \pm 0.29^{\mathrm{AB}}$ & $2.87 \pm 0.12^{\mathrm{ABCDE}}$ & $24.62 \pm 0.43^{A}$ \\
\hline WH-1105 & $1.55 \pm 0.07 \mathrm{ABC}$ & $0.82 \pm 0.19^{C}$ & $2.57 \pm 0.14^{\mathrm{ABCD}}$ & $1.59 \pm 0.80^{\mathrm{ABC}}$ & $4.43 \pm 0.23^{\mathrm{AB}}$ & $2.98 \pm 0.28^{A}$ & $7.37 \pm 1.38^{\mathrm{AB}}$ & $3.37 \pm 0.18^{\mathrm{AB}}$ & $24.70 \pm 0.93^{A}$ \\
\hline
\end{tabular}

Data are presented as the mean $\pm S D$. Means with different superscripts in column differ significantly $(p \leq 0.05) . n=3$. 
protein in different Pakistani wheat varieties, which are relatively lower than those observed in this study and numerous other studies.

The amino acid concentrations (in grams per $100 \mathrm{~g}$ of protein) in flours of the different wheat varieties varied: aspartic, 3.28-6.76; serine, 4.17-5.18; glycine, 4.31-7.11; alanine, 5.628.70 ; arginine, $2.10-3.35$; tyrosine, $3.03-4.10$; cystine, $0.68-$ 4.32; proline, 3.32-14.98; threonine, 0.94-1.96; histidine, $0.82-$ 1.86; valine, 0.82-3.52; methionine, 0.57-2.88; phenylalanine, 2.83-5.56; isoleucine, 2.74-3.77; leucine, 6.31-9.30; and lysine, 1.27-3.61 (Tables 5, 6). Tryptophan got destroyed and was not detected. Significant $(p \leq 0.05)$ differences were observed in all essential amino acids. Among the non-essential amino acids, aspartic acid, glycine, alanine, arginine, cystine, and proline showed significant $(p \leq 0.05)$ differences, whereas serine, tyrosine, and arginine varied non-significantly $(p \geq$ 0.05). Anjum et al. (15); Wang et al. (47); Jood et al. (48) and Alijosius et al. (49) reported the following concentrations of amino acids (in grams per $100 \mathrm{~g}$ protein): aspartic acid, 3.93-6.60; serine, 3.35-5.69; glycine, 2.81-6.78; alanine, 0.304.02; arginine, 1.55-7.01; tyrosine, 1.39-4.82; cystine, 2.07-2.30; proline, 7.17-15.38; threonine, 2.40-4.05; histidine, 1.23-5.24; valine, 2.99-6.59; methionine, 0.75-2.70; phenylalanine, 4.215.47; isoleucine, 1.89-4.04; leucine, 3.78-7.62; and lysine, 2.053.14. Most of the values obtained agreed satisfactorily and were within the range; however, the mean concentration of alanine was somewhat higher and those of threonine, histidine, and valine were lower than those reported previously. Differences in the amino acid composition in flours of the different wheat varieties are attributed to growing environmental conditions like $\mathrm{CO}_{2}$ concentration and temperature (47), wheat types hard, soft, or medium, the protein content of the flour, the extraction rate (50), the genetic makeup of the cultivars, and the application of fertilizers $(15,51)$.

The non-essential amino acids (NEAA) comprising aspartic acid, glutamic acid, serine, glycine, alanine, arginine, tyrosine, cysteine, and proline constituted $65.85-76.19 \%$ of the total amino acids (Table 5). The NEAA are associated with gluten proteins (gliadin + glutenin) and play an important role in the end product use of wheat flour. The essential amino acids (EAA), which included threonine, histidine, valine, methionine, phenylalanine, isoleucine, leucine, and lysine (Table 6), accounted for 19.13-27.43\% of the total amino acids. Statistically, significant $(p \leq 0.05)$ differences were observed in both NEAA and EAA. The flour of wheat variety PBW550 was observed as having the highest and that of SW-2 the lowest percentage of NEAA. The highest proportion of EAA was observed in the wheat variety SW-2 and the lowest in PBW-660. The amino acid score (AAS) is used to predict the completeness of a particular protein. A score of $100 \%$ or more represents the EAA in the particular protein being equal to or more than the reference protein, and the protein is termed as a complete protein; however, if the score is $<100$, the protein under study is termed as an incomplete protein. The individual and total AAS of EAA are given in Table 7. Most of the scores were $<100 \%$, which indicated that the test protein was incomplete. The mean AAS of threonine, valine, phenylalanine, histidine, methionine,

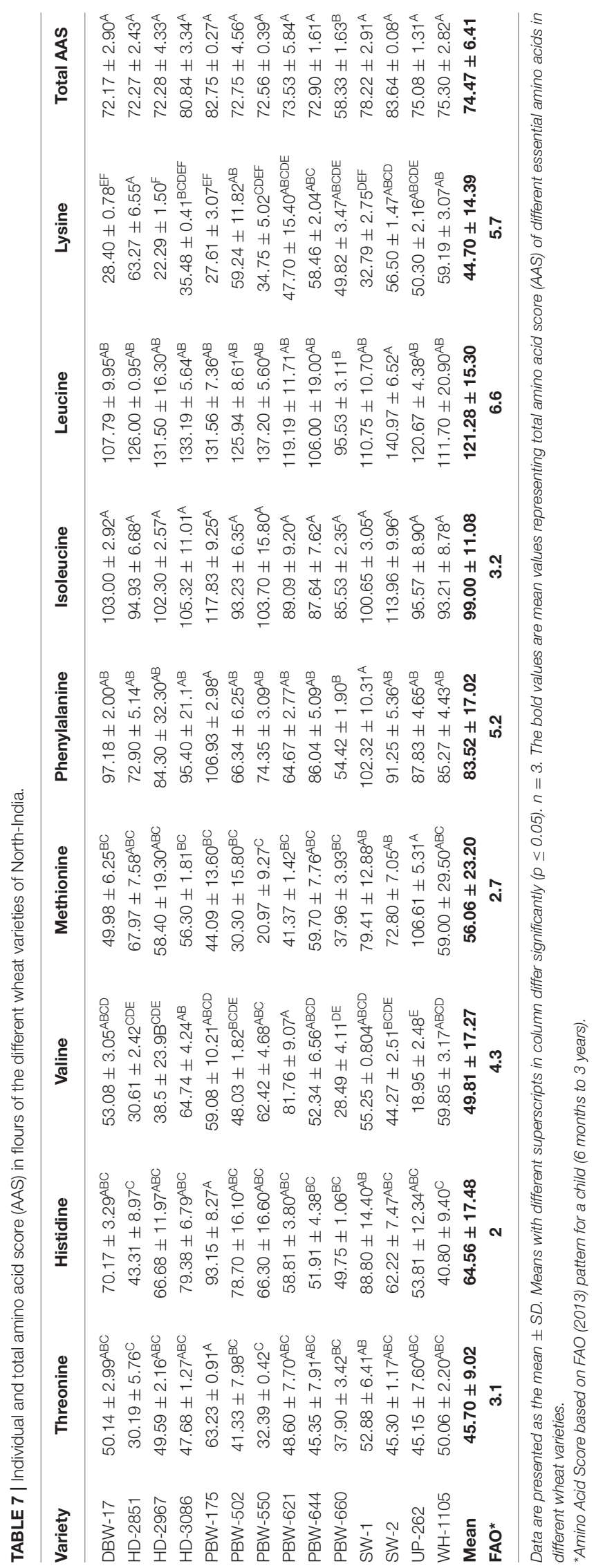


and lysine in almost all wheat varieties was $<100 \%$. Leucine and isoleucine had AAS of either more than $100 \%$ or close to $100 \%$ in most wheat varieties. The AAS of lysine was the lowest, having a mean score of $44.70 \%$, and was thus the first limiting amino acid in the flour of the different wheat varieties. Jiang et al. (52) also reported lysine as the first limiting amino acid in different wheat varieties, with a mean AAS of $49.8 \%$. Similar results have also been reported by Anjum et al. (15) and Jood et al. (48). The total amino acid score ranged from 58.33 to $83.64 \%$. Significant $(p \leq 0.05)$ differences were observed in the total amino acid score between the wheat varieties. Wheat variety SW-2 showed the highest and PBW-660 the lowest total amino acid score. The higher EEA as well as the total amino acid score for wheat variety SW-2 may be attributed to the low amount of gluten proteins and higher albumin + globulin content (data not shown, article in press).

The study was further extended to determine the proportions of the different amino acid groups (Table 8). The total percentage of amino acids was in the range of $91.43-99.99 \mathrm{~g} / 100 \mathrm{~g}$ protein for flours of the different wheat varieties. Basic amino acids constituted 5.29-7.52 g/100 g protein of the total amino acids and were statistically non-significant $(p \geq 0.05)$. Acidic amino acids accounted for $33.98-41.74 \mathrm{~g} / 100 \mathrm{~g}$ protein of the total amino acids and were significantly $(p \leq 0.05)$ highest for PBW-175 and lowest for UP-262. The results demonstrated wheat flour to be more acidic in nature. Aromatic amino acids constituted $6.49-9.46 \mathrm{~g} / 100 \mathrm{~g}$ protein of the total amino acids and showed a significant $(p \leq 0.05)$ difference, being highest for PBW175 and lowest for PBW-621. The proportion of non-polar amino acids accounted for $29.43-38.61 \mathrm{~g} / 100 \mathrm{~g}$ protein of the total amino acids, being significantly $(p \leq 0.05)$ highest for HD-2851 and lowest for UP-262. Polar and sulfur amino acids accounted for $7.00-12.82 \mathrm{~g} / 100 \mathrm{~g}$ protein and $1.55-6.43 \mathrm{~g} / 100 \mathrm{~g}$ protein of the total amino acids, respectively. Statistically, the highest percentages of both polar and sulfur amino acids were observed in SW-1 and the lowest in PBW-502. Hydroxy amino acids accounted for $5.42-6.92 \mathrm{~g} / 100 \mathrm{~g}$ protein of the total amino acids. The highest proportion of sulfur amino acids was observed in PBW-175 and the lowest in HD-2851. The arginine/lysine ratio varied significantly ( $p \leq 0.05$ ) from 0.59 to 2.19 , being highest for HD-2851 and lowest for HD-2967.

\section{SDS-PAGE of Wheat Flour}

The SDS-PAGE of defatted wheat flour (total flour proteins) from the different wheat cultivars of North India under reducing conditions is presented in Figure 1. The wheat varieties showed the presence of 19-23 polypeptides with a molecular weight range of $4.4-120.8 \mathrm{kDa}$. The total flour proteins were categorized into four subgroups on the basis of the location of the bands and the molecular mass of the different polypeptides: (i) high-molecularweight glutenin subunit (HMW-GS; $M_{\mathrm{w}}=65.1-120.8 \mathrm{kDa}$ ); (ii) $\omega$-gliadin $\left(M_{\mathrm{w}}=50.7-64.6 \mathrm{kDa}\right)$; (iii) $\alpha$-, $\beta$-, and $\gamma$-gliadin/lowmolecular-weight glutenin subunit (LMW-GS; $M_{\mathrm{W}}=27.1-50.1$ $\mathrm{kDa})$; and (iv) $\mathrm{A}+\mathrm{G}\left(M_{\mathrm{w}}=4.4-26.9 \mathrm{kDa}\right)$. DuPont et al. (53) documented the total flour protein and reported HMW-GS in the molecular weight range $70-112 \mathrm{kDa}, \omega$-gliadin $\left(M_{\mathrm{w}}=\right.$ 50-64.6 kDa), $\alpha-, \beta$-, and $\gamma$-gliadin/LMW-GS (30-45 kDa), and

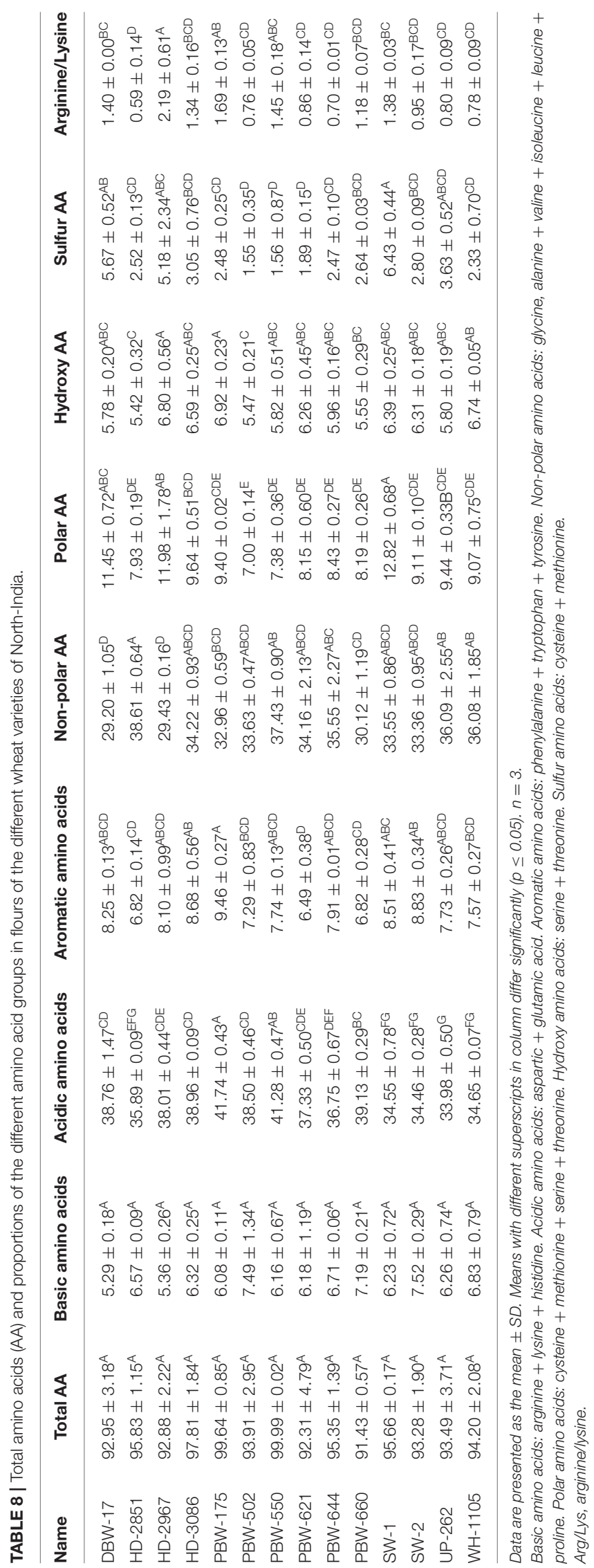




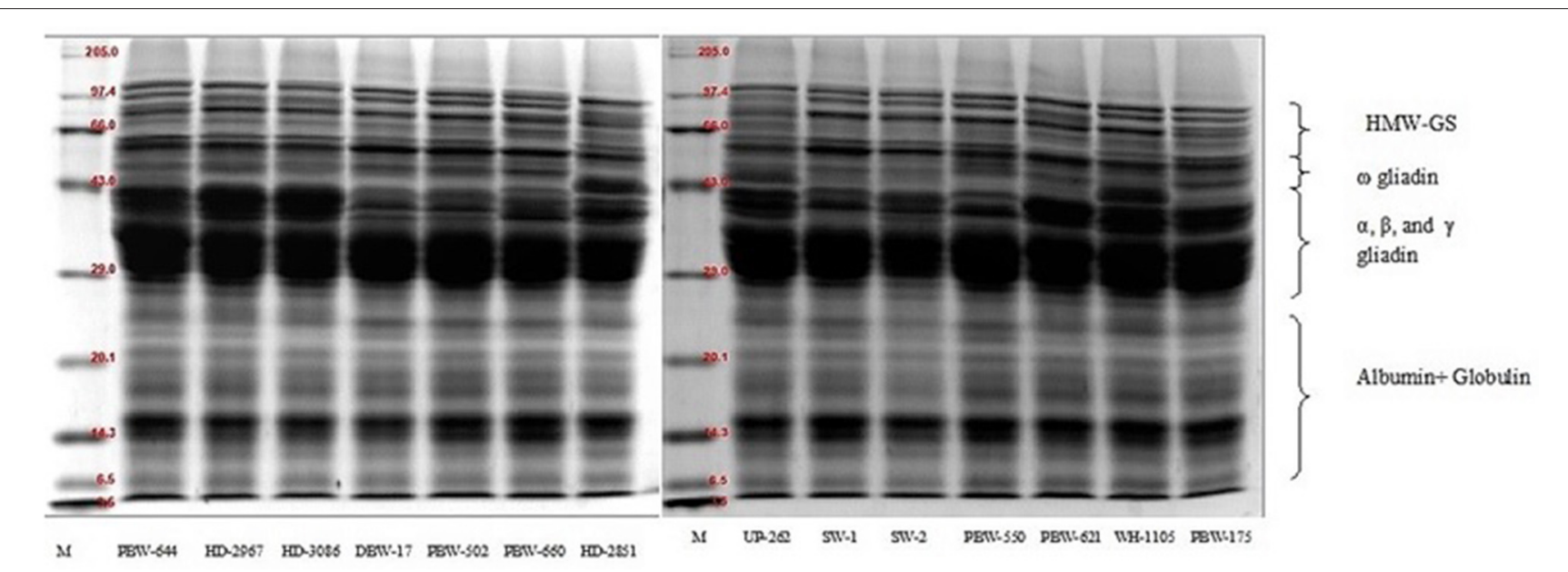

FIGURE 1 | SDS-PAGE patterns of total flour proteins of the different wheat varieties of North India under reducing conditions using $12 \%$ resolving gel.

TABLE 9 | Proportion of total proteins in flours of the different wheat varieties under reducing conditions.

\begin{tabular}{|c|c|c|c|c|c|}
\hline Variety & HMW-GS & $\omega$-gliadin & $\alpha-, \beta-, \gamma$-gliadin/LMW-GS & $\mathbf{A}+\mathbf{G}$ & HMW-GS/LMW-GS \\
\hline DBW-17 & $10.24 \pm 0.97^{\mathrm{AB}}$ & $9.69 \pm 4.90^{\mathrm{A}}$ & $22.30 \pm 4.22^{A}$ & $57.77 \pm 0.29^{A}$ & $0.46 \pm 0.04^{\mathrm{A}}$ \\
\hline HD-2851 & $12.22 \pm 0.23^{\mathrm{AB}}$ & $5.79 \pm 0.09^{A}$ & $26.05 \pm 3.00^{A}$ & $55.94 \pm 2.68^{A}$ & $0.47 \pm 0.06^{A}$ \\
\hline HD-2967 & $12.27 \pm 1.14^{\mathrm{AB}}$ & $7.98 \pm 2.70^{A}$ & $18.971 \pm 0.26^{A}$ & $60.78 \pm 3.58^{A}$ & $0.65 \pm 0.07^{A}$ \\
\hline HD-3086 & $12.76 \pm 1.77^{\mathrm{AB}}$ & $6.83 \pm 0.79^{A}$ & $20.37 \pm 1.44^{\mathrm{A}}$ & $60.04 \pm 4.00^{\mathrm{A}}$ & $0.63 \pm 0.04^{\mathrm{A}}$ \\
\hline PBW-175 & $10.87 \pm 0.72^{A B}$ & $4.47 \pm 0.14^{\mathrm{A}}$ & $28.19 \pm 6.34^{A}$ & $56.48 \pm 5.75^{A}$ & $0.40 \pm 0.12^{\mathrm{A}}$ \\
\hline PBW-502 & $15.07 \pm 2.64^{\mathrm{AB}}$ & $11.25 \pm 4.43^{\mathrm{A}}$ & $20.81 \pm 6.55^{A}$ & $52.87 \pm 8.33^{A}$ & $0.78 \pm 0.37^{A}$ \\
\hline PBW-550 & $12.15 \pm 3.58^{\mathrm{AB}}$ & $3.82 \pm 0.10^{A}$ & $18.76 \pm 0.32^{A}$ & $65.27 \pm 3.16^{A}$ & $0.65 \pm 0.20^{A}$ \\
\hline PBW-621 & $9.138 \pm 1.18^{\mathrm{B}}$ & $9.38 \pm 1.98^{\mathrm{A}}$ & $31.81 \pm 5.63^{A}$ & $49.67 \pm 4.82^{A}$ & $0.29 \pm 0.01^{A}$ \\
\hline PBW-644 & $13.293 \pm 1.34^{\mathrm{AB}}$ & $5.77 \pm 0.33^{\mathrm{A}}$ & $21.14 \pm 6.44^{A}$ & $59.80 \pm 4.77^{A}$ & $0.67 \pm 0.27^{A}$ \\
\hline PBW-660 & $16.33 \pm 2.45^{A}$ & $13.09 \pm 1.80^{\mathrm{A}}$ & $20.97 \pm 2.96^{A}$ & $49.61 \pm 7.22^{\mathrm{A}}$ & $0.78 \pm 0.01^{A}$ \\
\hline SW-1 & $8.05 \pm 1.44^{\mathrm{B}}$ & $9.52 \pm 3.27^{A}$ & $25.58 \pm 1.69^{A}$ & $56.85 \pm 3.01^{A}$ & $0.32 \pm 0.08^{A}$ \\
\hline SW-2 & $10.07 \pm 1.43^{\mathrm{AB}}$ & $6.67 \pm 0.66^{A}$ & $18.36 \pm 1.32^{\mathrm{A}}$ & $64.90 \pm 0.78^{A}$ & $0.55 \pm 0.12^{\mathrm{A}}$ \\
\hline UP-262 & $8.44 \pm 1.97^{\mathrm{B}}$ & $5.97 \pm 0.14^{\mathrm{A}}$ & $25.81 \pm 6.29^{A}$ & $59.78 \pm 8.40^{A}$ & $0.33 \pm 0.00^{A}$ \\
\hline WH-1105 & $10.66 \pm 1.52^{\mathrm{AB}}$ & $4.47 \pm 3.64^{\mathrm{A}}$ & $23.04 \pm 8.02^{\mathrm{A}}$ & $61.83 \pm 2.86^{A}$ & $0.51 \pm 0.24^{\mathrm{A}}$ \\
\hline
\end{tabular}

Data are presented as the mean $\pm S D$. Means with different superscripts in the column differ significantly $(p \leq 0.05) . n=2$.

HMW-GS, high-molecular-weight glutenin subunit; LMW-GS, low-molecular-weight glutenin subunit.

low-molecular-mass albumins in the molecular weight range 6$30 \mathrm{kDa}$. The variations in the molecular mass between the two studies might be due to the genetic makeup of the cultivars and the growing environment conditions. Each wheat variety showed the presence of four HMW-GS, except SW-1 and SW-2, which resolved into three HMW-GS. Anjum et al. (54) reported that common wheat possesses three to five HMW-GS. The $\omega$-gliadin consisted of two to three polypeptides depending on the variety. All the wheat varieties showed the presence of two $\omega$-gliadin polypeptides, except PBW-502 and PBW-175, which resolved into three bands. High polymorphism both in the number as well as the intensity was observed in the molecular weight range 35.1$42.8 \mathrm{kDa}$, which corresponds to the $\alpha$-, $\beta$-, and $\gamma$-gliadin/LMWGS region. Low-intensity polypeptide chains around 35.1-43.6 $\mathrm{kDa}$ were spotted in the wheat varieties DBW-17, PBW-502, PBW-660, SW-1, and SW-2. The 35.1-43.6-kDa region can thus be used as a genetic biomarker to differentiate wheat varieties (55). The resolution of the protein bands between $26.1-34.5 \mathrm{kDa}$ was not good enough so that the several individual components could be identified. Wheat varieties HD-2851 and WH-1105 both were distinguished by the presence of prominent high-intensity bands around 42.8 and $41.1 \mathrm{kDa}$, respectively. Irrespective of the wheat variety, the polypeptides in the molecular weight range 4.4-26.9 kDa, which corresponds to the A + G proteins, did not show any significant variation and were almost identical. A little to no polymorphism in both albumin and globulin has also been documented by other authors $(56,57)$.

The proportions of the different flour proteins determined densitometrically are given in Table 9 and Figure S2. HMWGS varied from 8.05 to $16.33 \%$ of the total extractable flour proteins. Statistically, a significant $(p \leq 0.05)$ difference was observed in HMW-GS among the wheat cultivars. The highest 
proportion of HMW-GS was observed in the wheat variety PBW660 and the lowest in SW-1. HMW-GS are minor components and constitute only $5-10 \%$ of the total protein, but account for nearly $70 \%$ variation in bread quality (58). HMW-GS are mainly responsible for providing elasticity to the dough, allowing the gas produced by the yeast to be trapped and making the products rise during fermentation. Several studies have found a strong positive correlation between the proportion of HMW-GS and the bread-making parameters $(12,59,60)$.

The proportion of $\omega$-gliadin ranged from 4.47 to $13.09 \%$ of the total extractable flour proteins. A non-significant $(p \geq$ $0.05)$ difference was observed in the $\omega$-gliadin proportion among the wheat varieties. The $\alpha-, \beta$-, and $\gamma$-gliadin/LMW-GS also varied non-significantly ( $p \geq 0.05$ ) from 18.36 to $31.81 \%$ of the total extractable flour proteins. The results are in concordance with those of other authors $(60,61)$ who found that $\alpha-, \beta$-, and $\gamma$-gliadin occur in high proportions compared to that of $\omega$-gliadin. Depending on their properties, various gliadin subfractions have been found to be differently associated with dough quality (59). Khatkar et al. (62) found that the addition of $\alpha-, \beta-, \gamma-$, and $\omega$-gliadin resulted in improved bread-making quality; however, the role of $\omega$-gliadin is debatable $(59,63)$. The percentage of $\mathrm{A}+\mathrm{G}$ determined after densitometric scanning of the SDS-PAGE gels was the highest among the different fractions and varied non-significantly ( $p \geq 0.05$ ) from 49.67 to $65.27 \%$ of the total flour proteins. Miháliková et al. (64) used SDSPAGE for the determination of the different flour proteins and obtained HMW-GS (10.35-20.53\%), LMW-GS (51.34-76.10\%), albumin, and globulin (11.48-34.12\%). The results revealed wide variations in the proportions of the different protein types, mainly LMW-GS and A + G. The differences may be because of the genetic makeup, seasonal variation, and the application of nitrogen fertilizers, which influence the balance of various protein fractions (11). The ratio of HMW-GS to LMW-GS ranged from 0.32 to 0.78 , but the variation was non-significant $(p \geq$ $0.05)$. Wheat varieties having a higher HMW-GS/LMW-GS ratio are generally associated with improved rheological and breadmaking qualities (12).

\section{Pearson's Correlation Coefficient}

Table S1 summarizes the Pearson's correlation coefficients between the various flour components and wheat grains. Wheat flour protein showed a significant positive relation with wheat kernel brightness $\left(L^{*}\right)$, yellowness $\left(b^{*}\right)$, the total color difference $(\Delta E)$, chroma, and hue. Wang et al. (65) also reported a significant relationship between the protein content of flour and the color parameters. Flour protein content (PC) was positively correlated with wet gluten $(r=0.621, p \leq 0.05)$ and dry gluten $(r=0.625, p \leq 0.05)$, which is expected because the flour protein content is mainly due to gluten proteins. A positive correlation between PC and gluten (both wet and dry) has also been reported earlier (66). PC showed no correlation with the sedimentation value (SV; $r=0.042$ ), which emphasized that SV should not be used as a sole criterion for determining protein quality as well as quantity. Panghal et al. (39) also reported a correlation of $r=0.091$ between PC and SV. No relationship between the protein content and any other SRC values except SCSRC $(r$ $=-0.598 ;, p \leq 0.05$ ) was found. Duyvejonck et al. (41) also did not find any significant relationship between the protein content and any of the SRC values. The protein content exhibited non-significant positive relations with HMW-GS $(r=0.286)$, $\omega$-gliadin $(r=0.119)$, and HMW-GS/LMW-GS $(r=0.248)$ and negative relations with LMW-GS/ $\alpha-, \beta$-, and $\gamma$-gliadin $(r=$ $-0.096)$ and $A+G(r=-0.130)$. Ash content was negatively correlated with $L^{*}(r=-0.655, p \leq 0.05)$ and $\Delta E(r=-0.672$, $p \leq 0.01)$. The results suggest that the lightness of the flour is controlled by the amount of ash, which in turn is directly controlled by bran contamination in flour. A similar relationship between flour brightness and ash content has been reported by Dennett and Trethowan (67).

Wet gluten was positively correlated with SV $(r=0.535, p \leq$ $0.05)$ and showed a strong positive relation with dry gluten $(r=$ 0.983 ) at the $0.01 \%$ level of significance. Gulia and Khatkar (66) also reported a correlation $(r=0.92, p \leq 0.01)$ between wet and dry gluten.

SV showed a significant positive correlation with GPI $(r=$ $0.559, p \leq 0.05)$ and a non-significant positive correlation with LASRC $(r=0.303)$. Flour brightness $\left(L^{*}\right)$ was negatively related with redness $\left(a^{*}\right)$, yellowness $\left(b^{*}\right)$, and chroma, respectively $(r=$ $-0.595, r=-0.585$, and $r=-0.587 ; p \leq 0.05)$ and positively with $\Delta E(r=0.989, p \leq 0.01)$, which reflected that the color parameters of flour are inversely related to each other, unlike color parameters in wheat grains which are positively related. The reason may be that the color in wheat kernels is due to the combination of various pigments which are mostly concentrated in the outer regions and removed during milling; in flour, it is mostly due to ash and bran contamination and only to a small extent by pigments. Similar results were obtained by Wang et al. (65).

$a^{*}$ was negatively correlated with $\Delta E(r=-0.560, p \leq 0.05)$ and hue $(r=-0.964, p \leq 0.01)$. WSRC was positively related with SUSRC $(r=0.570, p \leq 0.05)$ and showed a strong positive correlation with SCSRC $(r=0.816, p \leq 0.01)$, which indicated that starch damage and pentosan content are the major factors determining water absorption in flour. WSRC also showed a non-significant positive correlation with LASRC $(r=0.472)$. The positive relation between water and the other SRC values is due to the ability of the water to hydrate and swell up all the major polymeric flour constituents. Similar results were reported by Pasha et al. (44). A positive correlation was observed between SUSRC and LASRC $(r=0.565, p \leq 0.05)$. LASRC showed a highly significant positive correlation with GPI ( $r=$ $0.791, p \leq 0.01)$. LASRC, GPI, and SV all reflect protein quality and gluten strength and are based on the swelling capacity of glutenin strands in the lactic acid medium, which might explain the positive relationship between them. A positive correlation between LASRC and SV was also reported by Karaduman (45). The ratio of HMW-GS to LMW-GS was found to be positively related with HMW-GS $(r=0.915)$ and negatively with LMWGS $(r=-0.791)$ at the $0.01 \%$ level of significance. $A+G$ was negatively related with $\omega$-gliadin $(r=-0.558, p \leq 0.05)$ and LMW-GS/ $\alpha-, \beta-$, and $\gamma$-gliadin $(r=-0.724, p \leq 0.01)$. A 
non-significant negative correlation was observed between PC and all the amino acids except aspartic acid, glutamic acid, and threonine, which showed positive correlations. An increase in PC is usually accompanied by a decrease in essential amino acids, particularly lysine, and has been reported several times $(51,68)$. The HMW-GS proportions were positively correlated with tyrosine $(r=0.535, p \leq 0.05)$ and negatively related with methionine $(r=-0.586)$, phenylalanine $(r=-0.579)$, and total essential amino acid (TEAA; $r=0.587$ ) at the $0.05 \%$ level of significance. HMW-GS also showed a non-significant positive relation with aspartic acid $(r=0.180)$, glutamic acid $(r=0.483)$, alanine $(r=0.506)$, arginine $(r=0.416)$, and total non-essential amino acid (TNEAA; $r=0.442$ ) and was negatively correlated with the essential amino acids. The ratio of HMW-GS to LMWGS was found to be significantly correlated with arginine $(r=$ $0.535)$ and tyrosine $(r=0.645)$. The HMW-GS/LMW-GS ratio also showed a non-significant positive correlation with TNEAA $(r=0.327)$ and a significant negative correlation with TEAA $(r$ $=-0.444)$. This reflects the importance of NEAA in dough and baking quality. HMW-GS are rich in tyrosine, and these amino acids, although low in concentrations, are involved in covalent bond formation involving tyrosine-tyrosine crosslinks between glutenins and gliadin (61). These covalent bonds are believed to play an important role in determining the properties and structure of gluten. A negative correlation was observed between $\omega$-gliadin and TEAA $(r=-0.560, p \leq 0.05)$. LMW-GS/ $\alpha-, \beta$ , and $\gamma$-gliadin, on the other hand, were positively correlated with the essential amino acids and showed negative relations with the non-essential amino acids. Glutamic acid showed a significant positive correlation with TNEAA $(r=0.678, p \leq$ $0.01)$, alanine $(r=0.684, p \leq 0.01)$, and tyrosine $(r=0.579$, $p \leq 0.05)$ and a negative correlation with methionine $(r=$ $-0.794, p \leq 0.01$ ), which is expected as glutamic acid is the predominant amino acid in wheat flour. A highly significant negative correlation $(r=-0.719, p \leq 0.01)$ was observed between cystine and lysine. Cystine is formed by two molecules of cysteine linked together by a disulfide linkage. Cysteine is known to form inter- and intrachain disulfide linkages between various gluten proteins (61), and such formation is believed to play an important role in the dough and baking quality, which might support a negative relation between increasing protein content and lysine. TNEAA was negatively related with TEAA, although non-significantly.

\section{REFERENCES}

1. Ramadas S, Kumar TMK, Singh GP. Wheat production in india: trends and prospects. In: Shah F, Khan Z, Iqbal A, Turan M, Olgun M, editors. Recent Advances in Grain Crops Research. London: Intech Open Limited (2019). p. 1-16. doi: 10.5772/intechopen.86341

2. Shewry PR, Hey SJ. The contribution of wheat to human diet and health. Food Energy Sec. (2015) 4:178-202. doi: 10.1002/FES3.64

3. FAO. Crop Prospects and Food Situation-Quarterly Global Report No. 1. Rome: FAO (2020).

4. Wani IA, Sogi DS, Gill BS. Physical and cooking characteristics of black gram (Phaseolus mungoo L.) cultivars grown in India. Int J Food Sci Technol. (2013) 48:2557-63. doi: 10.1111/ijfs.12249

\section{CONCLUSION}

The study was helpful in understanding the diversity of wheat varieties grown in different geographical regions of North India in terms of their grain, flour, protein profiling, proportions of the different proteins, and the amino acid composition. The study concluded that the wheat varieties showed significant diversity in almost all the quality traits. Moderate protein, gluten content, SDS sedimentation value, and solvent retention capacity suggest that most of these varieties have weak gluten strength more suitable for chapatti and biscuit making. Polymorphism both in the number and intensity of bands was observed particularly in the HMW-GS, $\omega$-gliadin, and the $\alpha, \beta$, and $\gamma$-gliadin/LMWGS region. Protein profiling of $\mathrm{A}+\mathrm{G}$ proteins did not show significant variations and they were almost identical. The wheat varieties HD-2967, HD-3086, PBW-502, PBW-644, and PBW-660, having better protein, gluten, sedimentation volume, proportion of HMW-GS, and higher HMW-GS/LMW-GS ratio, can be further improved for their amino acid composition. Our results could be beneficial to plant breeders, millers, and bakers in selecting those wheat varieties with better quality characteristics for end product use without compromising the nutritional value and thus can also be used for future breeding programs.

\section{DATA AVAILABILITY STATEMENT}

The raw data supporting the conclusions of this article will be made available by the authors, without undue reservation.

\section{AUTHOR CONTRIBUTIONS}

RS collected the samples, performed the analysis, interpreted and analyzed the data, and wrote the manuscript, with contributions from TS and MR. DS along with RS planned the work, checked the manuscript thoroughly, and made critical revisions before final submission. MB helped in the statistical analysis. All authors read and checked the manuscript properly before submission.

\section{SUPPLEMENTARY MATERIAL}

The Supplementary Material for this article can be found online at: https://www.frontiersin.org/articles/10.3389/fnut.2020. 00141/full\#supplementary-material

5. Omobuwajo TO, Akande EA, Sanni LA. Selected physical, mechanical and aerodynamic properties of African breadfruit (Treculia africana) seeds. J Food Eng. (1999) 40:241-4. doi: 10.1016/S0260-8774(99)00060-6

6. Sahin S, Sumnu SG. Physical Properties of Foods. New York, NY: Springer US (2006).

7. Lachman J, Hejtmánková A, Orsák M, Popov M, Martinek P. Tocotrienols and tocopherols in colored-grain wheat, tritordeum and barley. Food Chem. (2018) 240:725-35. doi: 10.1016/j.foodchem.2017.07.123

8. Kundu M, Khatkar BS, Gulia N. Assessment of chapatti quality of wheat varieties based on physicochemical, rheological and sensory traits. Food Chem. (2017) 226:95-101. doi: 10.1016/j.foodchem.2016.12.046

9. Kundu M, Gulia N, Khatkar BS. Diversity in quality traits of Indian wheat cultivars: grain, whole wheat flour and protein charateristics. Int J 
Innov Res Sci Eng Technol. (2016) 5:17590-4. doi: 10.15680/IJIRSET.2016. 0510014

10. Prabhasankar P, Manohar RS, Gowda LR, Sai R. Physicochemical and biochemical characterisation of selected wheat cultivars and their correlation to chapati making quality. Eur Food Res Technol. (2002) 214:131-7. doi: 10.1007/s00217-001-0435-4

11. Xue C, Matros A, Mock HP, Mühling KH. Protein composition and baking quality of wheat flour as affected by split nitrogen application. Front Plant Sci. (2019) 10:642. doi: 10.3389/fpls.2019.00642

12. Dhaka V, Khatkar BS. Effects of gliadin/glutenin and HMW-GS/LMW-GS ratio on dough rheological properties and bread-making potential of wheat varieties. J Food Qual. (2015) 38:71-82. doi: 10.1111/jfq.12122

13. Tomić J, Torbica A, Pojić M, Rakita S, Popović L, Strelec I. Albumins characterization in relation to rheological properties and enzymatic activity of wheat flour dough. J Agric Sci Technol. (2015) 17:805-16. Available online at: http://jast.modares.ac.ir/article-23-6880-en.html

14. Tomić J, Torbica A, Popović L, Hristov N, Nikolovski B. Wheat breadmaking properties in dependance on wheat enzymes status and climate conditions. Food Chem. (2016) 199:565-72. doi: 10.1016/j.foodchem.2015.12.031

15. Anjum FM, Ahmad I, Butt MS, Sheikh MA, Pasha I. Amino acid composition of spring wheats and losses of lysine during chapati baking. J Food Compos Anal. (2005) 18:523-32. doi: 10.1016/j.jfca.2004.04.009

16. FAO. Dietary Protein Quality Evaluation in Human Nutrition: Report of an FAO Expert Consultation. Rome: FAO (2013).

17. Anjum FM, Ahmad I, Butt MS, Arshad MU, Pasha I. Improvement in end-use quality of spring wheat varieties grown in different eras. Food Chem. (2008) 106:482-6. doi: 10.1016/j.foodchem.2007.06.011

18. Mohsenin NN. Physical Properties of Plant and Animal Materials: Structure, Physical Characteristics and Mechanical Properties. New York, NY: Gordon and Breach Science Publishers (1970).

19. Bhattacharya KR. Milling quality of rice. In: Rice Quality: A Guide to Rice Properties and Analysis. Sawston; Cambridge, UK: Woodhead Publishing (2011). p. 61-99. doi: 10.1533/9780857092793.61

20. AACC. Approved Methods of Analysis. 11th ed. St. Paul, MN: Cereals \& Grains Association (2010).

21. Ram S, Dawar V, Singh RP, Shoran J. Application of solvent retention capacity tests for the prediction of mixing properties of wheat flour. J Cereal Sci. (2005) 42:261-6. doi: 10.1016/j.jcs.2005.04.005

22. Kweon M, Slade L, Levine H. Solvent retention capacity (SRC) testing of wheat flour: principles and value in predicting flour functionality in different wheatbased food processes and in wheat breeding-a review. Cereal Chem. (2011) 88:537-52. doi: 10.1094/CCHEM-07-11-0092

23. Axford DWE, McDermott EE, Redman DG. Note on the sodium dodecyl sulphate test of breadmaking quality: comparison with Pelshenke and Zeleny test. Cereal Chem. (1979) 56:582-4.

24. Siddiqi RA, Singh Sogi D, Sehajpal PK. Effect of short-term sourdough fermentation on wheat protein. Cogent Food Agric. (2016) 2:1132983. doi: 10.1080/23311932.2015.1132983

25. DuPont FM, Chan R, Lopez R, Vensel WH. Sequential extraction and quantitative recovery of gliadins, glutenins, and other proteins from small samples of wheat flour. J Agric Food Chem. (2005) 53:1575-84. doi: 10.1021/jf0486971

26. Bhise SR, Kaur A, Manikantan MR. Mositure dependent physical properties of wheat grain (PBW 621). Int J Eng Pract Res. (2014) 3:3-8. doi: 10.14355/ijepr.2014.0302.03

27. Williams P, El-Haramein FJ, Nakkoul H, Rihawi S. Crop Quality Evaluation Methods and Guidelines. 14th ed. Technical manual No. 14. Alspoo: International Center for Agricultural Research in the Dry Areas (ICARDA) (1986).

28. Baljeet SY, Yogesh S, Ritika BY. Physicochemical and rheological properties of Indian wheat varieties of Triticum aestivum. Qual Assur Saf Crops Foods. (2017) 9:369-82. doi: 10.3920/QAS2015.0745

29. Garg M, Chawla M, Chunduri V, Kumar R, Sharma S, Sharma NK, et al. Transfer of grain colors to elite wheat cultivars and their characterization. $J$ Cereal Sci. (2016) 71:138-44. doi: 10.1016/j.jcs.2016.08.004

30. Martinek P, Jirsa OO, Vaculová KK, Chrpová J, Watanabe N, Burešová V, et al. Use of wheat gene resources with different grain colour in breeding. 64 Tagung der Vereinigung der Pflanzenzüchter und Saatgutkaufleute Österreichs. (2014) 4:75-8.
31. Punia S, Singh K, Kumar A. Difference in protein content of wheat (Triticum aestivum $\mathrm{L}$.): effect on functional, pasting, color and antioxidant properties. $J$ Saudi Soc Agric Sci. (2019) 18:378-84. doi: 10.1016/j.jssas.2017.12.005

32. Memon AA, Mahar I, Memon R, Soomro S, Harnly J, Memon N, et al. Impact of flour particle size on nutrient and phenolic acid composition of commercial wheat varieties. J Food Compos Anal. (2020) 86:103358. doi: 10.1016/j.jfca.2019.103358

33. Biesiekierski JR. What is gluten? J Gastroenterol Hepatol. (2017) 32:78-81. doi: $10.1111 /$ jgh. 13703

34. Daaloul Bouacha O, Nouaigui S, Rezgui S. Effects of N and K fertilizers on durum wheat quality in different environments. J Cereal Sci. (2014) 59:9-14. doi: $10.1016 /$ j.jcs.2013.11.003

35. Asim SM, Anwaar A, Rai Muhammad A, Nadeem M. Comprehensive identification and evaluation of selected wheat cultivars for their relationship to pan bread quality. J Food Process Preserv. (2018) 42:e13670. doi: 10.1111/jfpp.13670

36. Carter BP, Morris CF, Anderson JA. Optimizing the SDS sedimentation test for end-use quality selection in a soft white and club wheat breeding program. Cereal Chem. (1999) 76:907-11. doi: 10.1094/CCHEM.1999.76.6.907

37. Eckert B, Amend T, Belitz H. The course of the SDS and Zeleny sedimentation tests for gluten quality and related phenomena studied using the light microscope. Z Lebensm Unters Forsch. (1993) 196:122-5.

38. Patil VR, Talati JG, Singh C, Parekh VB, Jadeja GC, Patil VR, et al. Genetic variation in glutenin protein composition of aestivum and durum wheat cultivars and its relationship with dough quality genetic variation in glutenin protein composition of aestivum and durum wheat cultivars and its relationship with dough quality. Int J Food Prop. (2015) 18:2393-408. doi: 10.1080/10942912.2014.980948

39. Panghal A, Chhikara N, Khatkar BS. Characterisation of Indian wheat varieties for chapatti (flat bread) quality. J Saudi Soc Agric Sci. (2017) 18:10711. doi: 10.1016/j.jssas.2017.02.005

40. Costa MS, Scholz MB dos S, Miranda MZ, Franco CML. Effect of glutenin subunits on the baking quality of Brazilian wheat genotypes. Bragantia. (2017) 76:11-22. doi: 10.1590/1678-4499.636

41. Duyvejonck AE, Lagrain B, Dornez E, Delcour JA, Courtin CM. Suitability of solvent retention capacity tests to assess the cookie and bread making quality of European wheat flours. LWT Food Sci Technol. (2012) 47:56-63. doi: 10.1016/j.lwt.2012.01.002

42. Jeon S, Baik BK, Kweon M. Solvent retention capacity application to assess soft wheat flour quality for making white-salted noodles. Cereal Chem. (2019) 96:497-507. doi: 10.1002/cche.10150

43. Lindgren A, Simsek S. Evaluation of hard red spring wheat mill stream fractions using solvent retention capacity test. J Food Process Preserv. (2016) 40:131-9. doi: 10.1111/jfpp. 12590

44. Pasha I, Anjum FM, Butt MS. Genotypic variation of spring wheats for solvent retention capacities in relation to end-use quality. LWT Food Sci Technol. (2009) 42:418-23. doi: 10.1016/j.lwt.2008.03.005

45. Karaduman Y. Assessing gluten strength with a new small-scale LASRC method useful for soft wheat breeding programs. Cereal Chem. (2019) 97:196204. doi: 10.1002/cche.10235

46. Hammed AM, Ozsisli B, Ohm JB, Simsek S. Relationship between solvent retention capacity and protein molecular weight distribution, quality characteristics, and breadmaking functionality of hard red spring wheat flour. Cereal Chem. (2015) 92:466-74. doi: 10.1094/CCHEM-12-140262-R

47. Wang J, Hasegawa T, Li L, Lam SK, Zhang X, Liu X, et al. Changes in grain protein and amino acids composition of wheat and rice under short-term increased $\left[\mathrm{CO}_{2}\right]$ and temperature of canopy air in a paddy from East China. New Phytol. (2019) 222:726-34. doi: 10.1111/nph.15661

48. Jood S, Kapoor AC, Singh R. Amino acid composition and chemical evaluation of protein quality of cereals as affected by insect infestation. Plant Foods Hum Nutr. (1995) 48:159-67. doi: 10.1007/BF01088312

49. Alijošius S, Švirmickas GJ, Bliznikas S, GruŽauskas R, Šašyte V, RacevičiuteStupeliene A, et al. Grain chemical composition of different varieties of winter cereals. Zemdirbyste Agric. (2016) 103:273-80. doi: 10.13080/z-a.2016. 103.035

50. Shoup FK, Pomeranz Y, Deyoe CW. Amino acid composition of wheat varieties and flours varying widely in bread-making potentialities. J Food Sci. (1966) 31:94-101. doi: 10.1111/j.1365-2621.1966.tb15420.x 
51. Zhang M, Ma D, Wang C, Zhao H, Zhu Y, Guo T. Responses of amino acid composition to nitrogen application in high- and low-protein wheat cultivars at two planting environments. Crop Sci. (2016) 56:1277-87. doi: 10.2135/cropsci2015.08.0504

52. Jiang X, Tian J, Hao Z, Zhang W. Protein content and amino acid composition in grains of wheat-related species. Agric Sci China. (2008) 7:2729. doi: 10.1016/S1671-2927(08)60066-8

53. DuPont FM, Samoil V, Chan R. Extraction of up to $95 \%$ of wheat (Triticum aestivum) flour protein using warm sodium dodecyl sulfate (SDS) without reduction or sonication. J Agric Food Chem. (2008) 56:7431-8. doi: 10.1021/jf800776b

54. Anjum FM, Khan MR, Din A, Saeed M, Pasha I, Arshad MU. Wheat gluten: high molecular weight glutenin subunits-structure, genetics, and relation to dough elasticity. J Food Sci. (2007) 72:R56-63. doi: 10.1111/j.1750-3841.2007.00292.x

55. Hailegiorgis D, Ca L, Sj Y. Composition and molecular weight distribution of albumin and globulin protein isolates from durum wheat genotypes. J Genet Mol Biol. (2019) 3:1-5. doi: 10.4236/ajps.2020.112011

56. Dvoráček V, Curn V. Evaluation of protein fractions as biochemical markers for identification of spelt wheat cultivars (Triticum spelta L.). Plant Soil Environ. (2003) 49:99-105. doi: 10.17221/4097-pse

57. Žilić S, Barać M, Pešić M, HadŽi-Tašković Šukalović V, Dodig D, Mladenović Drinić S, et al. Genetic variability of albumin-globulin content, and lipoxygenase, peroxidase activities among bread and durum wheat genotypes. Genetika. (2011) 43:503-16. doi: 10.2298/GENSR $1103503 Z$

58. Wang S, Yu Z, Cao M, Shen X, Li N, Li X, et al. Molecular mechanisms of HMW glutenin subunits from $1 \mathrm{Sl}$ genome of Aegilops longissima positively affecting wheat breadmaking quality. PLoS ONE. (2013) 8:e0058947. doi: 10.1371/journal.pone.0058947

59. Zhang Y, Hu M, Liu Q, Sun L, Chen X, Lv L, et al. Deletion of high-molecular-weight glutenin subunits in wheat significantly reduced dough strength and bread-baking quality. BMC Plant Biol. (2018) 18:319. doi: $10.1186 /$ s12870-018-1530-Z

60. Wieser H, Kieffer R. Correlations of the amount of gluten protein types to the technological properties of wheat flours determined on a micro-scale. J Cereal Sci. (2001) 34:19-27. doi: 10.1006/jcrs.2000.0385
61. Wieser H. Chemistry of gluten proteins. Food Microbiol. (2007) 24:115-9. doi: 10.1016/j.fm.2006.07.004

62. Khatkar BS, Fido RJ, Tatham AS, Schofield JD. Functional properties of wheat gliadins. I. Effects on mixing characteristics and bread making quality. J Cereal Sci. (2002) 35:299-306. doi: 10.1006/jcrs.2001.0429

63. Barak S, Mudgil D, Khatkar BS. Biochemical and functional properties of wheat gliadins: a review. Crit Rev Food Sci Nutr. (2015) 55:357-68. doi: 10.1080/10408398.2012.654863

64. Miháliková D, Gálová Z, Petrovičová L, Chnapek M. Polymorfizmus bielkovín vo vybraných slovenských odrodách pšenice letnej pouŽitím SDSPAGE. J Central Eur Agric. (2016) 17:970-85. doi: 10.5513/JCEA01/17. 4.1800

65. Wang C, Kovacs MIP, Fowler DB, Holley R. Effects of protein content and composition on white noodle making quality: color. Cereal Chem. (2004) 81:777-84. doi: 10.1094/CCHEM.2004.81.6.777

66. Gulia N, Khatkar BS. Quantitative and qualitative assessment of wheat gluten proteins and their contribution to instant noodle quality. Int J Food Prop. (2015) 18:1648-63. doi: 10.1080/10942912.2013.805765

67. Dennett AL, Trethowan RM. Milling efficiency of triticale grain for commercial flour production. J Cereal Sci. (2013) 57:527-30. doi: $10.1016 /$ j.jcs.2013.03.002

68. Biel W, Stankowski S, Jaroszewska A, Puzyński S, Bośko P. The influence of selected agronomic factors on the chemical composition of spelt wheat (Triticum aestivum ssp. spelta L.) grain. J Integr Agric. (2016) 15:1763-9. doi: 10.1016/S2095-3119(15)61211-4

Conflict of Interest: The authors declare that the research was conducted in the absence of any commercial or financial relationships that could be construed as a potential conflict of interest.

Copyright (C) 2020 Siddiqi, Singh, Rani, Sogi and Bhat. This is an open-access article distributed under the terms of the Creative Commons Attribution License (CC BY). The use, distribution or reproduction in other forums is permitted, provided the original author(s) and the copyright owner(s) are credited and that the original publication in this journal is cited, in accordance with accepted academic practice. No use, distribution or reproduction is permitted which does not comply with these terms. 